\title{
A White Paper on Controlled Digital Lending of Library Books
}

\author{
David R. Hansen \& Kyle K. Courtney ${ }^{1}$
}

TABLE OF CONTENTS

I. THE 20TH CENTURY BOOK PROBLEM .......................................................................................

II. THE LEGAL FRAMEWORK: FIRST SALE AND FAIR USE ..................................................

III. CONTROLLED DIGITAL LENDING AS FAIR USE..................................................................

IV. TAKEAWAYS: SYSTEM DESIGN AND RISK MITIGATION …………………….....................32

V. CONCLUSION....................................................................................................................42

This paper is about how libraries can legally lend digital copies of books. It explains the legal and policy rationales for the process - "controlled digital lending" - as well as a variety of risk factors and practical considerations that can guide libraries seeking to implement such lending. We write this paper in support of the Position Statement on Controlled Digital Lending, ${ }^{2}$ a document endorsed by many libraries, librarians, and legal experts. Our goal is to help libraries and their lawyers become more comfortable with the concept by more

${ }^{1}$ These institutional affiliations are for identification purposes only. David R. Hansen is Associate University Librarian for Research, Collections \& Scholarly Communications at Duke University Libraries. Kyle K. Courtney is Copyright Advisor and Program Manager at Harvard Library's Office for Scholarly Communication.

We're grateful for comments and suggestions from a number of people including Lila Bailey, Anne Gilliland, Mary Minow, Rachael Samberg, Pamela Samuelson, Jason Schultz, Kevin Smith, and Michelle $\mathrm{Wu}$. Thanks also to staff, participants, and attendees who helped hone our thoughts in sessions we held on this topic at the 2018 American Association of Law Libraries Annual Meeting, the 2018 Kraemer Copyright Conference, the Lillian Goldman Law Library at Yale University, the 2018 Copyright First Responders Pacific Northwest workshop, and the 2018 University Information Policy Officers Meeting hosted by The Ohio State University Libraries. We also offer our profound thanks to Lacey Chrabaszcz, OSC Copyright Fellow, for her careful editing and Bluebook expertise.

(C) 2018 David Hansen and Kyle Courtney. This paper is licensed for reuse under a Creative Commons Attribution 4.0 International License, https://creativecommons.org/licenses/by/4.0/.

2 We are both contributors to that statement. We wrote this paper independently, with comments and input from selected Statement drafters, signatories, and other parties. 
fully explaining the legal rationale for controlled digital lending, as well as situations in which this rationale is the strongest.

For this paper we define "controlled digital lending" (CDL) just as the Statement does:

CDL enables a library to circulate a digitized title in place of a physical one in a controlled manner. Under this approach, a library may only loan simultaneously the number of copies that it has legitimately acquired, usually through purchase or donation. For example, if a library owns three copies of a title and digitizes one copy, it may use CDL to circulate one digital copy and two print, or three digital copies, or two digital copies and one print; in all cases, it could only circulate the same number of copies that it owned before digitization. Essentially, CDL must maintain an "owned to loaned" ratio. Circulation in any format is controlled so that only one user can use any given copy at a time, for a limited time. Further, CDL systems generally employ appropriate technical measures to prevent users from retaining a permanent copy or distributing additional copies. ${ }^{3}$

Thus, CDL would permit circulation of copies equal to those that had been legitimately acquired by the participating libraries. When the digital copy is being read by a patron, however, the corresponding physical copy is restricted and unavailable for consultation, so there is no situation in which the library is getting use of two copies for the price of one. A library can lend a physical book to a patron through standard circulation or to another library through interlibrary loan. What CDL does do is shift that lending to a new format that opens up access possibilities for readers with disabilities, physical access limitations, research efficiency needs, or other needs for digitally-accessible content.

A CDL system is not a brand-new concept. There are multiple versions of CDL-like systems currently being used in libraries. The idea was first explored in the pioneering article "Building a Collaborative Digital Collection: A Necessary Evolution in Libraries" 4 by Michelle Wu, Professor of Law and Law Library Director at Georgetown University School of Law. Later, the Internet Archive created the "Open Library: Digital Lending Library" project, which has

3 Position Statement on Controlled Digital Lending by Libraries (hereafter "Statement") available at https://controlleddigitallending.org/statement

${ }^{4}$ Michelle M. Wu, Building a Collaborative Digital Collection: A Necessary Evolution in Libraries, 103 LaW LiBr. J. 527 (2011). See also Michelle M. Wu, Piece-by-Piece Review of Digitize-andLend Projects Through the Lens of Copyright and Fair Use, 36 LEGAL REF. SERV.Q. 51 (2017). 
successfully utilized a unique CDL-like system for the past 8 years. ${ }^{5}$ Multiple libraries have now harnessed the same CDL system and partnered with Internet Archive to loan their digital copies of books. These partners include large library systems such as the Boston Public Library, to smaller specialized libraries such as the Allen County Public Library, which houses the largest genealogical collection of any public library in the country. ${ }^{6}$ And, most recently, Georgetown Law Library launched its own CDL service. ${ }^{7}$

At its core, $\mathrm{CDL}$ is about replicating with digital lending the legal and economically significant aspects of physical lending. To do so, we libraries must truly exercise control in the process. The Statement identifies six specific requirements to do so. It states that for $\mathrm{CDL}$, libraries should:

(1) ensure that original works are acquired lawfully;

(2) apply CDL only to works that are owned and not licensed;

(3) limit the total number of copies in any format in circulation at any time to the number of physical copies the library lawfully owns (maintain an "owned to loaned" ratio);

(4) lend each digital version only to a single user at a time just as a physical copy would be loaned;

(5) limit the time period for each lend to one that is analogous to physical lending; and

(6) use digital rights management to prevent wholesale copying and redistribution.

Our principal legal argument for controlled digital lending is that fair use an "equitable rule of reason" 8 - permits libraries to do online what they have always done with physical collections under the first sale doctrine: lend books. The first sale doctrine, codified in Section 109 of the Copyright Act, provides that anyone who legally acquires a copyrighted work from the copyright holder receives the right to sell, display, or otherwise dispose of that particular copy, notwithstanding the interests of the copyright owner. This is how libraries loan books. Additionally, fair use ultimately asks, "whether the copyright law's goal

${ }^{5}$ See Open Library, https:/ / openlibrary.org (last visited Sept. 13, 2018). See also Geoffrey A. Fowler, Libraries Have a Novel Idea, WALL ST. J. (June 29, 2010), https://www.wsj.com/articles/SB10001424052748703279704575335193054884632.

6 Internet Archive, Digital Lending Library, Internet Archive Blogs (June 28, 2010), https://blog.archive.org/2010/06/28/digital-lending-library [https://perma.cc/R4A2-QUW6].

7American Association of Law Libraries, Transforming Our Libraries from Analog to Digital: A Vision For 2020, American Association of Law Libraries Webinar, https://www.aallnet.org/recording/transforming-libraries-analog-digital-vision-2020/ [https://perma.cc/Q9AB-AEW4].

${ }^{8}$ H.R. REP. No 94-1476, 94th Cong., 2d Sess 65 (1976). 
of promoting the Progress of Science and useful Arts would be better served by allowing the use than by preventing it." 9 In this case we believe it would be. Controlled digital lending as we conceive it is premised on the idea that libraries can embrace their traditional lending role to the digital environment. The system we propose maintains the market balance long-recognized by the courts and Congress as between rightsholders and libraries, ${ }^{10}$ and makes it possible for libraries to fulfill their "vital function in society"11 by enabling the lending of books to benefit the general learning, research, and intellectual enrichment of readers by allowing them limited and controlled digital access to materials online.

\section{The 20th Century BoOK Problem}

For decades, libraries and cultural institutions have sought to provide greater access to their collections with the hope of reaching a broader and more diverse set of readers. ${ }^{12}$ A confluence of technological advances and expanding copyright protection have driven the problem.

Copyright terms are now extremely long (95 years or more for many published works), "formalities" that once required rightsholders to take action to obtain and retain rights have been eliminated, rights are infinitely divisible among private parties causing uncertainty about ownership, and the quantity of copyright-eligible works has exploded with the technological ability to easily and quickly create and publish new works. ${ }^{13}$ Librarians now puzzle over questions such as whether a work is actually still protected by copyright (did the rightsholder comply with applicable U.S. copyright formalities?), who owns

9 Bill Graham Archives v. Dorling Kindersley Ltd., 448 F.3d 605, 608 (2d Cir. 2006).

${ }^{10}$ For users generally, the House Judiciary Committee Report on the 1976 Copyright Act explains that under section 109(a), "[a] library that has acquired ownership of a copy is entitled to lend it under any conditions it chooses to impose." H.R. Rep. No. 94-1476, § 109, at 79 (1976). The Copyright Act in several other places identifies special considerations with respect to libraries. See 17 U.S.C. $§ 108$ (specific exceptions to reproduce and distribute for libraries and archives); 17 U.S.C. § 504(c)(2) (special damage exceptions for libraries and archives).

11 U.S. COPYRIGHT OfFICE, DMCA SECTION 104 REPORT 105 (2001), https:/ / perma.cc/59TU2NKI [hereinafter, DMCA SECTION 104 REPORT].

12 For example, Project Gutenberg is a volunteer effort to digitize and archive cultural works, to "encourage the creation and distribution of books." It was founded in 1971 by Michael S. Hart and is the oldest digital library. See http://www.gutenberg.org/. Others efforts include the HathiTrust digital library, https:// www.hathitrust.org/, OpenLibrary, http://openlibrary.org/, and - with a corporate partner -Google Books, https://books.google.com/.

${ }^{13}$ In the context of the "orphan works" problem, these and related causes are explained in more detail in David R. Hansen, Orphan Works: Causes of the Problem (Berkeley Digital Library Copyright Project White Paper No. 3, 2012), https://ssrn.com/abstract=2038068. 
digital rights (publisher or author?), and whether the rightsholder can be found (or is the work an orphan?). Attempting to clearly answer those questions on a title-by-title basis has proven costly, ${ }^{14}$ making full digital access for large numbers of works based on rightsholder permission difficult. Particularly for books and other published materials for which there was once an active market, libraries have not yet been able to provide broad full-text access online. ${ }^{15}$

Many 20th Century books are not available for purchase as new copies in print or as digital versions online. ${ }^{16}$ Libraries would like to provide digital access, but many rightsholders have not offered those titles for sale in that format. The morass of rights management, combined with the orphan works problem and the ever-increasing copyright length, has made it complicated to see a path forward to broad digital access.

For modern libraries with users whose research and information use patterns mean they look to digital access first, ${ }^{17}$ this means that a whole world of research is effectively invisible to a variety of types of users. For some, the inability to physically travel to a library because of their remote physical location, economic wherewithal, or homebound limitations means that physical lending is not practical. For others, physical access is a matter of great inefficiency in their research and learning. For users with print disabilities - those who currently

14 See, e.g., Cornell University Library, Response to the Notice of Inquiry Concerning Orphan Works (Mar. 23, 2005), https:/ / perma.cc/NZ8W-UWMK (spending \$50,000 in staff time to identify rightsholders for 198 books); Carnegie Mellon University Libraries, Response to Notice of Inquiry about Orphan Works 2 (Mar. 22, 2005), https:// perma.cc/95XW-TV4Z (similar). See also Maggie Dickson, Due Diligence, Futile Effort: Copyright and the Digitization of the Thomas E. Watson Papers, 73 AM. ARCHIVIST 626 (2010), https:/ / perma.cc/QD2X-F3D8 (reporting on similar efforts in the context of special collections). The same is true in jurisdictions with relative clarity about what steps are necessary for such a search. See Victoria Stobo, Kris Erickson, Aura Bertoni \& Flavia Guerrieri, Report 3: Current Best Practices among Cultural Heritage Institutions when Dealing with Copyright Orphan Works and Analysis of Crowdsourcing Options (EnDOW Report 3, May 2018), https://perma.cc/SQH8-H3CT ("This study shows that digitization remains a paradox for [cultural heritage institutions]. Rights clearance in particular remains expensive and ranges considerably depending on the nature of the work and the approach taken by the institution.").

15 In contrast, U.S. libraries have increasingly relied on fair use to provide full-text access to archival and special collections materials for which original markets are more clearly limited. See DAVID R. HANSEN, DigITIZING ORPHAN WORKS: REDUCING LEGAL RISKS FOR OPEN ACCESS TO COPYRIGHTED ORPHAN WORKS, 111 (Kyle K. Courtney \& Peter Suber eds., Harvard Library 2016), https:/ / dash.harvard.edu/handle/1/27840430 (listing 30 different online digital collections in which libraries have openly disclosed the likely orphan status of their materials and their reliance on fair use as a basis for online digital access).

16 See Paul J. Heald, How Copyright Keeps Works Disappeared, 11 J. EMPIRICAL L. STUDIES 829 (2014).

17 See, e.g., John Palfrey \& Urs Gasser, Born Digital: Understanding the First Generation of Digital Natives (Basic Books, 2010). 
have some digital access to print collections due to the fair use holding in the HathiTrust case which addressed copying and access of books for print-disabled users $^{18}$-access is currently hampered by hurdles that require users to selfidentify disabilities and request special access to digital copies. For a large research library, this means holdings of millions of volumes, already purchased at a cost of hundreds of millions of dollars, are not accessible in a format that is more meaningful and easier to use for many researchers today. ${ }^{19}$

For books primarily from the mid-20 th $C e n t u r y$, presumptively still protected by copyright, but not currently available in electronic form from their rightsholders, we believe CDL holds significant promise. We also believe the legal rationale for lending these works is among the strongest of all types of works. ${ }^{20}$ Some of these books may well be described as "orphaned," without identifiable owners. Others may have identifiable owners, but are in practice neglected, unavailable in the digital marketplace and with no plan for revitalization in modern formats. For all, it means that they are not fully meeting the basic goals of copyright to promote "the Progress of Science and the useful Arts." 21 Their unavailability online benefits neither creators nor the reading public.

So, how can libraries provide access? First, we start with a detailed look at the two fundamental copyright law doctrines that already empower libraries to fulfill their missions: first sale and fair use.

18 See Authors Guild, Inc. v. HathiTrust, 755 F.3d 87, 101 (2d Cir. 2014) (finding it fair use for the HathiTrust digital library to provide access to print-disabled patrons under a system which requires patrons to "submit documentation from a qualified expert verifying that the disability prevents him or her from reading printed materials" before gaining access).

${ }^{19}$ Some of the most popular, commercially-viable books remain in print and are available in a variety of formats. For many 20th Century books, however, the window for commercial viability passes only a few years after first publication. Several copyright scholars have studied the phenomenon. See William M. Landes \& Richard A. Posner, Indefinitely Renewable Copyright, 70 U. CHI. L. REV. 471, 474 (2003); Paul J. Heald, Property Rights and the Efficient Exploitation of Copyrighted Works: An Empirical Analysis of Public Domain and Copyrighted Fiction Bestsellers, 92 MiNN. L. REV. 1031 (2008).

20 Controlled digital lending may be well adapted to other types of library lending, for example of serials, or of audio or audiovisual works, or even archival materials. The same principles may also support other related activities such as users' donation of ebooks to libraries. The market dynamics and use scenarios that those situations raise are different enough that we believe they merit separate treatment in a subsequent paper. See Paul J. Heald, The Demand for Out-of-Print Works and their (Un)Availability in Alternative Markets (Illinois Public Law and Legal Theory Research Papers Series No. 14-31, 2014), http:/ / papers.ssrn.com/abstract $=2409118$ (noting differences between the book markets and music markets).

${ }^{21}$ U.S. CONST., art. I, § 8, cl. 8. 


\section{The Legal FrameWORK: First SALE AND FAIR USE}

Section 106 of the Copyright Act enumerates the basic bundle of rights granted to copyright owners: the exclusive right to control reproduction of the work, public distribution of the work, public performances, public displays, and creation of derivative works. ${ }^{22}$ For individuals who want to lend or resell copies of works they have purchased, the rightsholder's exclusive right to control public distribution ${ }^{23}$ is potentially problematic. But, the rights granted in Section 106 are limited by a number of statutory exceptions. Section 109, the statutory first sale doctrine, is one such provision. ${ }^{24}$ It states that "[n]otwithstanding the provisions of section 106(3) [the public distribution right], the owner of a particular copy or phonorecord lawfully made under this title, or any person authorized by such owner, is entitled, without the authority of the copyright owner, to sell or otherwise dispose of the possession of that copy or phonorecord." 25

\section{A. First Sale Doctrine}

Entire industries and enterprises are built upon the first sale doctrine. Libraries were built on it. eBay relies on the provision when it permits users to sell copyright protected works through its site, ${ }^{26}$ used record stores similarly rely on it to distribute copies they have acquired, college bookstores buy and sell used textbooks based on this doctrine, and libraries rely on it to lend physical books in their collections. The first sale doctrine balances the rights of copyright owners to distribute with those of purchasers to dispose of their copies as they wish. Without it, copyright holders could enforce rights in the "secondary market," which would impact selling, loaning, or gifting any copyrighted work. The rationale is that "once the copyright owner places a copyrighted item in the stream of commerce by selling it, he has exhausted his exclusive statutory right to control its distribution." 27

A critical limitation in the text of Section 109 is that it only allows the "owner of a copy" to "sell or otherwise dispose" of that particular copy. With distribution of physical copies, such as lending a print book to a library user, that framework works well enough. But to date, courts and legal scholars have

2217 U.S.C. $\S 106$.

${ }^{23}$ Id. ("copies or phonorecords of the copyrighted work to the public by sale or other transfer of ownership, or by rental, lease, or lending").

2417 U.S.C. $\$ 109$ (2018). Although the first sale doctrine has been cast as primarily a matter of statutory law, it has a more expansive, common-law pedigree. See Aaron Perzanowski \& Jason Schultz, Digital Exhaustion, 58 UCLA L. Rev. 889, 912-22 (2011).

${ }^{25} I d$. at $\S 109$ (a).

26 UMG Recordings, Inc. v. Augusto, 628 F.3d 1175, 1180 (9th Cir. 2011).

27 Quality King Distributors, Inc. v. L'anza Research Intern., Inc., 523 U.S. 135, 152 (1998). 
struggled to identify what is a "particular" copy in the digital realm. ${ }^{28}$ Is the transfer of a digital copy from one device to another the transfer of a particular copy or the creation of a new copy? While we wait for the courts to sort out this statutory interpretation issue, libraries that seek to utilize CDL should still be able to apply the first sale doctrine's rationale in the fair use context.

Much of the literature on first sale applied in the digital environment recognizes that library lending raises unique concerns requiring special treatment. ${ }^{29}$ Though other use scenarios are certainly possible, we view library lending uses as special, as detailed in the sections below, and of all uses among the most likely to be justified under a fair use rationale. Indeed, several libraries have already engaged in limited CDL for years without issue, indicating perhaps a tacit acknowledgement of the strength of their legal position. ${ }^{30}$ So, while the concept of digital first sale may have many potential applications, our focus is on a narrow and specialized use by libraries. We limit our analysis to noncommercial, controlled, digital lending by U.S. libraries of digitized copies of print books held in their collections. ${ }^{31}$

\section{B. Fair Use}

That brings us next to fair use. Fair use applies to uses implicating any or all of the copyright holder's exclusive rights, including both public distribution and the right to control reproductions. ${ }^{32}$ Like the first sale doctrine, fair use is widely used and entire industries (e.g., home recording device manufacturers, search engines, filmmakers, publishers ) rely on it. ${ }^{33}$ Described as an "equitable rule of

28 Capitol Records, LLC v. ReDigi Inc., 934 F. Supp. 2d 640, 649 (S.D.N.Y. 2013).

29 DMCA SECTION 104 REPORT, supra note 11, at 104-105 (addressing library specific issues);

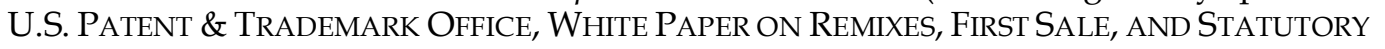
DAMAGES 48, 50 (2016), https:// perma.cc/RJ7Z-5REZ [hereinafter USPTO FIRST SALE STUDY], Brief of Amici Curiae American Library Association, Association of College and Research Libraries, Association of Research Libraries, and Internet Archive in Support of Reversal, Capitol Records, LLC v. Redigi Inc., Case No. 16-2321-cv (2d Cir. 2016), https://perma.cc/79AL-649N; Michelle Wu, Piece by Piece Review of Digitize-and-Lend Projects Through the Lens of Copyright and Fair Use, 36 LEGAL REF. SERV. Q. 51 (2017), https://doi.org/10.1080/0270319X.2017.1359059.

${ }^{30}$ Geoggrey A. Fowler, Libraries Have a Novel Idea, WALL ST. J. (June 29, 2010) https:// perma.cc/H4H3-ZJXZ (describing efforts by the Internet Archive, Boston Public Library and others to engage in digital lending activities).

${ }^{31}$ Fair use is a US legal concept. Our analysis is limited to U.S. law.

3217 U.S.C. $§ 107$ (2018)(Notwithstanding the provisions of sections 106 and 106A, the fair use of a copyrighted work ... is not an infringement of copyright.").

33 See, e.g., COMPUTER \& COMMUNiCATIONS INDUSTRY ASSOCIATION, FAIR USE IN THE U.S. ECONOMY: ECONOMIC CONTRIBUTION OF INDUSTRIES RELYING ON FAIR USE (2017), https://perma.cc/EGH4-N88D (summarizing industries reliant on fair use). 
reason," fair use was developed by the courts beginning in the 1800s. ${ }^{34}$ In 1976 Congress codified the doctrine in Section 107 of the Copyright Act, which provides that "the fair use of a copyrighted work ... for purposes such as criticism, comment, news reporting, teaching (including multiple copies for classroom use), scholarship, or research is not copyright infringement." 35 Those examples are "illustrative and not limitative" however. ${ }^{36}$ To apply the doctrine, Congress identified four non-exclusive factors that courts and users should consider:

"(1) the purpose and character of the use, including whether such use is of a commercial nature or is for nonprofit educational purposes;

(2) the nature of the copyrighted work;

(3) the amount and substantiality of the portion used in relation to the copyrighted work as a whole; and

(4) the effect of the use upon the potential market for or value of the copyrighted work." 37

Those four statutory factors must not be "treated in isolation, one from another. All are to be explored, and the results weighed together, in light of the purposes of copyright." 38 Ultimately, the fair use inquiry asks, "whether the copyright law's goal of promoting the Progress of Science and useful Arts would be better served by allowing the use than by preventing it." 39 The next section examines how this flexible doctrine of fair use, together with first sale, supports CDL.

\section{Controlled Digital LeNDing AS FaIR Use}

The basic concept of applying first sale principles to digital transactions is not new, either as justified under the first sale doctrine alone, as fair use, or through some combination of the two together. The U.S. Copyright Office, in 2001, studied the issue of "digital first sale," soliciting comments that exhibited a range of views about whether the first sale doctrine does or should be made to apply to digital transactions. In part because the use of digital technology was so new at

34 See Folsom v. Marsh, 9. F. Cas. 342 (C.C.D. Mass. 1841); Matthew Sag, The Pre-History of Fair Use, 76 BROOKLYN L. REV. 1371 (2011).

3517 U.S.C. § 107 (2018).

${ }^{36}$ Campbell v. Acuff-Rose Music, Inc., 510 U.S. 569, 577-78 (1994).

3717 U.S.C. $\S 107$ (2018)

38 Campbell, 510 U.S. at 577-78 (1994).

39 Bill Graham Archives v. Dorling Kindersley Ltd., 448 F.3d 605, 608 (2d Cir. 2006). 
the time, and despite hearing strong arguments and evidence from advocates on both sides of the issue, the Office concluded that it does not and should not apply to digital transactions, mostly because the technology in 2001 was unable to sufficiently guarantee the "owned to loaned" ratio. Instead, it was simply a good faith effort to "forward and delete" copies on a case-by-case basis. ${ }^{40}$ More recently, the United States Department of Commerce studied the issue itself and released a white paper in 2016 expressing its own conclusion: the technology and licensing markets were not yet adequately developed, leading it to adopt a "wait and see approach." 41 Scholarship on "digital first sale" and related concepts has flourished in recent years. ${ }^{42}$ And most recently Capitol Records v. ReDigi, LLC, has raised the question of how these doctrines apply to a commercial, digital resale market for mp3s. ${ }^{43}$

Again, the literature on digital first sale recognizes that library most likely will require special treatment. ${ }^{44}$ Other use scenarios are possible, and, as detailed below, we view library lending uses as special. And we also believe that these library uses, of all the varying digital uses, are among the most likely to be justified under a fair use rationale. Several libraries have already engaged in limited CDL for years without issue. ${ }^{45}$ It can be inferred that this fact indicates a

${ }^{40}$ DMCA SECTION 104 REPORT, supra note 11, at 80, 90 (“[W] hen the owner of a lawful copy of a copyrighted work digitally transmits that work in a way that exercises the reproduction right without authorization, section 109 does not provide a defense to infringement" and "we recommend no change to section 109 at this time").

41 USPTO FIRST SALE STUDY, supra note 29, at 58 (examining a wide range of potential applications, including library uses, but ultimately concluding that "we cannot at this time recommend extending the first sale doctrine to apply to digital transmissions of copyrighted works.").

42 For some representative work, see Aaron Perzanowski \& Jason Schultz, Digital Exhaustion, 58 UCLA L. Rev. 889 (2011); R. Anthony Reese, The First Sale Doctrine in the Era of Digital Networks, 44 B.C. L. Rev. 577, 584 (2003); Victor F. Calaba, Quibbles 'n Bits: Making A Digital First Sale Doctrine Feasible, 9 Mich. TeLECOMM. TeCH. L. ReV. 1 (2002).

43934 F. Supp. 2d 640 (2013), on appeal, Case No. 16-2321-cv (2d Cir. 2016). The district court in this case concluded that neither first sale nor fair use applied, though its analysis on the latter was abbreviated and the case is currently on appeal before the Second Circuit Court of Appeal.

44 DMCA SECTION 104 REPORT, supra note 11, at 104-105 (addressing library specific issues); USPTO FIRST SALE STUDY, supra note 29, at 48, 50; Brief of Amici Curiae American Library Association, Association of College and Research Libraries, Association of Research Libraries, and Internet Archive in Support of Reversal, Capitol Records, LLC v. Redigi Inc., Case No. 162321-cv (2d Cir. 2016), https:// perma.cc/79AL-649N; Michelle Wu, Piece by Piece Review of Digitize-and-Lend Projects Through the Lens of Copyright and Fair Use, 36 LEGAL REF. SERV. Q. 51 (2017), https:// doi.org/10.1080/0270319X.2017.1359059.

${ }^{45}$ Geoggrey A. Fowler, Libraries Have a Novel Idea, WALL ST. J. (June 29, 2010) https://perma.cc/H4H3-ZJXZ (describing efforts by the Internet Archive, Boston Public Library and others to engage in digital lending activities). 
tacit acknowledgement of the strength of their legal position. Our focus is on these narrow and specialized use by libraries. Again, we limit our analysis to non-commercial, controlled, digital lending by U.S. libraries of digitized copies of print books held in their collections. ${ }^{46}$

In applying fair use, not every factor in the analysis will be highly relevant in every situation. ${ }^{47}$ As we will show, for CDL, the first factor, "purpose and character of the use," and the fourth factor "effect on the potential market" are the most significant.

\section{A. The Purpose and Character of the Use}

Under the first fair use factor, "purpose and character of the use," two characteristics of CDL stand out, weighing this factor in favor of fair use: 1) CDL's purpose aligns closely with the statutory purpose of the first sale doctrine, and 2) the noncommercial, temporary, character of the use to fulfill research and learning purposes are aligned with the statutory examples of fair use as well as the underlying purposes of the copyright system to disseminate knowledge.

\section{CDL's Alignment with the Statutory Purpose of First Sale}

The core concept with CDL is that it closely mimics the economic transaction that Congress has already provided for through the first sale doctrine under Section 109. The purpose of the use with CDL is to fulfill the statutory objectives and balance of rights already identified by Congress in Section 109, effectuating that balance considering a new technological use not contemplated at the time Section 109 was enacted..$^{48}$ The crux of the proposition is that the purpose and intent of Section 109 should positively influence the "purpose and character" assessment in the fair use analysis. ${ }^{49}$

${ }^{46}$ Fair use is a US legal concept. Our analysis is limited to U.S. law.

47 See Kienitz v. Sconnie Nation LLC, 766 F.3d 756, 759 (7th Cir. 2014) (in a case involving a tshirt that used a mayor's official photograph in protest to his decision to shut down their annual block party, dismissing two of the four factors as having not much "bite in this litigation," "[ $t$ ]he other statutory factors don't do much in this case.").

48 Section 109(a) was enacted in 1976. Congress has requested study of potential changes, but has not substantially modified its text since. See Pub. L. 105-304, title I, § 104, Oct. 28, 1998, 112

Stat. 2876, requiring a study on Section 109 (and 117) and their effect on electronic commerce and associated technology.

${ }^{49}$ For a more detailed discussion, see Jonathan Band, The Impact of Substantial Compliance with Copyright Exceptions on Fair Use, 59 J. COPYRIGHT SOC'Y U.S.A. 453 (2012) (discussing at length the interaction between Section 108-library and archives exceptions - with fair use). See also at Jonathan Band, The Impact of Specific Exceptions on Fair Use: An Update, $63 \mathrm{~J}$. COPYRIGHT SOCY. U.S.A. 325 (2016). 
The Copyright Act does not address how fair use should interact with other provisions of the law..$^{50}$ In fact, rightsholders have in some cases argued that if a specific statutory exception exists, that specific exception should preclude application of the more general doctrine of fair use. When raised, courts have largely rejected that argument. For example, in Sega Enterprises Ltd. v. Accolade, Inc., ${ }^{51}$ Sega argued that the presence of a specific statutory exception regarding computer programs (Section 117) precluded Accolade from asserting a fair use defense for copying and disassembling Sega's computer program. The Ninth Circuit found Sega's argument "verges on the frivolous." 52 The court instead construed Section 117 and fair use together, the former defining a "a narrow category of copying that is lawful per se" and the latter establishing a broader "defense to an otherwise valid claim of copyright infringement." "The fact that Congress has not chosen to provide a per se exemption to section 106 for disassembly does not mean that particular instances of disassembly may not constitute fair use." 53

As a matter of copyright policy, the presence of a specific copyright exception (or, in some cases, other provisions of federal law) provides persuasive evidence of the kinds of purposes that should be favored in the fair use assessment. ${ }^{54}$ What better evidence of the types of uses that align with the goals of the copyright than those most similar to ones Congress has specifically authorized? While not extensively litigated, a number of cases indicate that this is the right approach, which we review here to give a sense of the strength of this position.

In Authors Guild v. HathiTrust, for example, one of the uses that the Authors Guild claimed was infringing was HathiTrust's digitization and full-text access to millions of volumes of in-copyright books for print-disabled users. In assessing HathiTrust's fair use defense, the Second Circuit looked closely at legislative history ${ }^{55}$ as well as other provisions of the law that spoke to access for the disabled. The Court cited the Americans with Disabilities Act as evidence of "Congress reaffirm[ing] its commitment to ameliorating the hardships faced by

50 One exception is Section 108(f)(4), which provides that the provisions of that nothing in that section, addressing specific library and archives preservation and access copying, "in any way affects the right of fair use as provided by section 107 [fair use]."

51977 F.2d 1510, 1521 (9th Cir. 1992). The plaintiffs in Authors Guild v. HathiTrust, 755 F.3d 87, 94 (2d Cir. 2014) raised a similar argument with respect to the role of Section 108 and 107.

52 Sega Enters. Ltd. v. Accolade,Inc., 977 F.2d 1510, 1520-21 (9th Cir. 1992).

53 Id. at 1521.

54 Band, supra note 49 , at 459 .

${ }^{55}$ HathiTrust, 755 F.3d at 102. 
the blind and print disabled." 56 The court also relied on Section 121 of the Copyright Act, which permits "authorized entities" to make accessible copies for the print disabled, as illustrating "Congress's intent that copyright law make appropriate accommodations for the blind and print disabled." 57

Some courts have pointed to broader policy objectives, both within and outside of the copyright act, as influencing the purpose and character analysis. For example, ${ }^{58}$ in Swatch Group Management Services Ltd. v. Bloomberg, L.P., Swatch argued that Bloomberg infringed its rights when it recorded and distributed a private conference call reporting earnings information from a foreign company. ${ }^{59}$ Ultimately concluding that the use was fair, the Second Circuit cited Securities and Exchange Commission ("SEC") public disclosure regulations as significant in assessing the purpose and character of Bloomberg's use. The court found that Bloomberg's purpose in obtaining and disseminating the recording at issue was to make important financial information about Swatch Group available to investors and analysts. "That kind of information is of critical importance to securities markets. Indeed, as Bloomberg points out, the SEC has mandated that when American companies disclose this kind of material nonpublic information, they must make it available to the public immediately. See Regulation FD, 17 C.F.R. $§ 243.100 .{ }^{\prime 60}$

The U.S. Copyright Office has also cited specific copyright exceptions as positively influencing the fair use assessment. Under Section 1201 of the copyright act, every three years the Office is required to make recommendations about proposed exceptions to Section 1201's prohibition on circumvention of technological protection measures. ${ }^{61}$ Under that provision, the Office must assess for each proposed exception whether users of the class of works are likely to be adversely affected by the anti-circumvention provision in their "ability to make noninfringing uses." 62 The Office has traditionally provided in-depth analysis of the lawfulness of the proposed uses. In its 2015 recommendations, the Office pointed to the basic purpose of other provisions as favorably affecting the

${ }^{56} I d$.

${ }^{57} \mathrm{Id}$.

58 Another example is Am. Inst. of Physics v. Winstead PC, 3:12-CV-1230-M, 2013 WL 6242843, at $* 9$ (N.D. Tex. Dec. 3, 2013) (copying of scientific articles as evidence of prior art in patent examination weighs the purpose and character assessment in favor of fair use in part because "Defendants' copying of NPL contributes to an efficient patent system").

59 Swatch Group Mgt. Servs Ltd. v. Bloomberg L.P., 756 F.3d 73, 82 (2d Cir. 2014).

${ }^{60} I d$.

6117 U.S.C. § 1201 (2018).

6217 U.S.C. $\S 1201(\mathrm{a})(1)(\mathrm{c})$. 
purpose and character assessment under the first fair use factor. Those include looking to Section 1201 exceptions for interoperability, Section 110 exceptions for nonprofit public performances and teaching, and Section 117 exceptions for computer program adaptation. ${ }^{63}$

For CDL, the purpose of the use is one that intends to mirror the basic purpose of first sale as embodied in Section 109. In Kirtsaeng v. John Wiley \& Sons, Inc., the Supreme Court recognized, "for at least a century the "first sale" doctrine has played an important role in American copyright law."64 It has a "common-law doctrine with an impeccable historic pedigree," that limits a rightsholders ability to restrain subsequent dispositions, facilitating competition "to the advantage of the consumer" 65 and freeing the courts "from the administrative burden of trying to enforce restrictions upon difficult-to-trace, readily movable goods." 66

As technology and markets have shifted, libraries employing CDL seek to use technology to hold up that same balance of rights while allowing users to access materials in formats that are most meaningful to them today. CDL promotes consumer choice in formats and platforms, while avoiding dragging courts into the thicket of restrictions and rights conflicts that would require extensive litigation to resolve. ${ }^{67} \mathrm{CDL}$ also preserves the balance of rights carved out by Congress through Section 109 by requiring libraries to have legitimately acquired their own copies and limiting access to digital surrogate copies on terms consistent with ownership of the physical copy. Under CDL, if one copy is purchased, a library can only lend one copy - either print or physical-out to a user at a time.

As appealing as the pure application of the principles of first sale to digital distribution may be, we recognize that standing alone, such uses may not tilt the "purpose and character" analysis in favor of the use in all circumstances. There are no cases on point directly addressing the interaction between Section 109 and

63 U.S. Copyright OfFice, Section 1201 RULEMAKING: SiXTH TRIENNIAL ProceEding to DETERMINE EXEMPTIONS TO THE PROHIBITION ON CIRCUMVENTION (2015), https:// www.copyright.gov/1201/2015/registers-recommendation.pdf.

${ }^{64}$ Kirtsaeng v. John Wiley \& Sons, Inc., 568 U.S. 519, 539 (2013). See also Impression Prod., Inc. v. Lexmark Int'l, Inc., 581 U.S. _ 137 S. Ct. 1523 (2017) (noting the importance of first sale in the patent context as well).

${ }^{65} \mathrm{Id}$.

${ }^{66} \mathrm{Id}$.

67 See Molly Shaffer Van Houweling, Author Autonomy and Atomism in Copyright Law, 96 VA. L. ReV. 549 (2010); See also Random H., Inc. v. Rosetta Books LLC, 150 F. Supp. $2 d 613$ (S.D.N.Y. 2001), aff'd, 283 F.3d 490 (2d Cir. 2002) (resolving contractual dispute between publisher and author over ownership of e-book rights). 
fair use. There are a few cases in the commercial context that come close, however. Those cases are primarily negative, though as we explain below we believe they are distinguishable from CDL applications, and one case is currently on appeal. First, Capitol Records, LLC v. ReDigi Inc., a district court decision currently on appeal. Capitol sued for copyright infringement over ReDigi's online service that facilitated resale of used digital music files. ReDigi's MediaManager software would allow an owner of a music file to upload their files to a "Cloud Locker," deleting the copy from the user's device and saving a copy to the cloud. Upon sale through the ReDigi marketplace, the file would be downloaded to the purchaser and simultaneously deleted from the Cloud Locker. ${ }^{68}$ The district court in that case assessed both ReDigi's fair use defense and a defense based on Section 109. It did not, however, assess the two provisions together. On Section 109's direct applicability, the court noted that the provision "by its own terms [is] limited to assertions of the public distribution right. .. ReDigi's service violates Capitol's reproduction right [and so] the first sale doctrine does not apply...."69

For fair use, the ReDigi court was fairly dismissive of the purpose factor, focusing almost exclusive on the commerciality of the program. The analysis was brief and considered almost none of the arguments laid out above. In honing in on the commerciality of the use, the court found that the purpose and character of the use weighed against a fair use finding. ${ }^{70}$ The court found the use to be "an essential component of ReDigi's commercial enterprise," and that the use was not "transformative." 71 Overall, the court concluded that fair use did not apply. While ReDigi is in some ways factually analogous to CDL, the district court's fair use analysis was so cursory and the future of that case so uncertain (the case is currently on appeal and awaiting a decision from the Second Circuit Court of Appeals) that its direct application for CDL remains far from clear. ${ }^{72}$

In a few other cases, defendants have tried unsuccessfully to employ an analogous "format shifting" defense, wherein physical copies were purchased, and digital access metered to users based on the number of copies purchased. For instance, in Wall Data Inc. v. Los Angeles County Sheriff's Dept, the L.A. Sheriff's Department purchased licenses for 3,663 copies of Wall Data's software. To make

${ }^{68}$ Capitol Records, LLC v. ReDigi Inc., 934 F. Supp. 2d 640, 645-46 (S.D.N.Y 2013) (The court rejected ReDigi's argument that "technological change has rendered its literal terms ambiguous" and so the court should construe the statute under Section 109 in favor of its use.).

${ }^{69} \mathrm{Id}$. at 655.

${ }^{70} \mathrm{Id}$.

${ }^{71} \mathrm{Id}$.

72 Capitol Records, LLC v. ReDigi Inc., Case No. 16-2321-cv (2d Cir. 2016). 
installation more efficient, the Sheriff's Department installed the software on all department computers (6,007 in total), but limited access to the software to a number of user accounts less than the total licenses purchased. In rejecting the Sheriff Department's fair use defense, the court did not explicitly consider first sale in its assessment, but focused instead on a few key characteristics: the use was not "transformative," 73 the use did not generally advance "public knowledge," or otherwise "enrich[] the general public through access to creative works," and the use was considered commercial, largely because it was made in effort to save the expense of purchasing an authorized copy from the known vendor. ${ }^{74}$

More recently, in Disney Enterprises, Inc. v. VidAngel, Inc., Disney sued VidAngel over its streaming video service, which provided access to edited copies of Disney films. For each user, VidAngel would purchase a physical DVD on behalf of the user, which VidAngel then copied, edited and streamed to the user online. Like in Wall Data, the court did not consider how the principles of the first sale doctrine help establish the "purpose and character" of the use under fair use. VidAngel conceded that its use was commercial, and the court did not consider the use to be transformative. Like with Wall Data, the streams were provided for videos with known copyright owners who themselves license rights to competing streaming services. ${ }^{75}$

One way these cases are distinguished is just that the issue was not raised; except for ReDigi (where the issue was only obliquely argued), first sale and the purpose and character assessment were not raised by the litigants or addressed by the court. The argument was not presented. Another, more significant distinguishing factor is that all three cases involved commercial uses, both in the specific application and in connection with a broader, functioning market place for the works used. This brings us to the second characteristic of CDL that we believe tilts the first factor analysis decidedly in favor of fair use: Libraries engaging in CDL are doing so for non-commercial research and learning purposes.

\section{CDL's Non-commercial Research and Learning Purpose}

Unlike commercial resale or streaming markets, library use of CDL is noncommercial and designed to promote public benefits by facilitating research and learning. The fair use statute explicitly instructs courts to look at "whether such

\footnotetext{
${ }^{73}$ Wall Data Inc. v. Los Angeles County Sheriff's Dept., 447 F.3d 769, 778-79 (9th Cir. 2006).

${ }^{74} \mathrm{Id}$.

75 Disney Enterprises, Inc. v. VidAngel, Inc., 869 F.3d 848, 861-62 (9th Cir. 2017).
} 
use is of a commercial nature or is for nonprofit educational purposes."76 And the Supreme Court has explained, "[t]he crux of the profit/nonprofit distinction is not whether the sole motive of the use is monetary gain but whether the user stands to profit from exploitation of the copyrighted material without paying the customary price."77

Libraries engaging in CDL, as we envision it, will not generate monetary profit. Given the costs of digitizing, building and maintaining the technical infrastructure necessary to lending digitally and controlling physical copies, and personnel time used to restrict print copies when its digital equivalent is circulating, libraries may spend considerable sums with no compensation. To be sure, libraries and their users would stand to benefit from CDL. We would not propose it if they did not. But under the CDL model we envision, libraries have already paid the customary price, and CDL limits access to a work to one person at a time. Further, when $20^{\text {th }}$ century books are in question, no market has emerged for digital access to the majority of these books, meaning that no digital access would otherwise be possible.

Libraries engaging in CDL are doing so to enable broad availability of knowledge for the purpose of promoting research, scholarship and learning. These are uses specifically mentioned as examples of fair use by Congress in the statute, ${ }^{78}$ and are at the core of the constitutional purpose of the copyright system. Library lending is a critical conduit for those activities, which courts have recognized. For example, in a 1973 case before the U.S. Court of Claims, a non-profit library's role in supporting scientific research by providing copies of articles to researchers was held to weigh strongly in favor of fair use. ${ }^{79}$ Even

7617 U.S.C. $\S 107$ (2018).

77 Harper \& Row Publishers, Inc. v. Nation Enterprises, 471 U.S. 539, 562 (1985). See also Sundeman v. Seajay Socy., Inc., 142 F.3d 194, 203 (4th Cir. 1998) (finding that where an archives provided a copy of an unpublished manuscript to a researcher, the purpose of the use favored fair use where there was no commercial or exploitative motive for the use).

7817 U.S.C. \$107. As stated above, most courts have addressed these examples as merely illustrative. A handful of courts have indicated that uses within these categories means that the "purpose and character" analysis presumptively falls in favor of fair use, though that presumption has not been adopted by most circuits. See NXIVM Corp. v. Ross Inst., 364 F.3d 471, 477 (2d Cir. 2004) ("[T]here is a strong presumption that factor one favors the defendant if the allegedly infringing work fits the description of uses described in section 107.") (quoting Wright v. Warner Books, Inc., 953 F.2d 731, 736 (2d Cir. 1991)).

79 Williams \& Wilkins Co. v. United States, 487 F.2d 1345, 1354 (Ct. Cl. 1973), aff'd by an equally divided court, 420 U.S. 376 (1975). In this case Williams \& Wilkins challenged the National Library of Medicine's photocopying practices for medical researchers. The U.S. Court of Claims observed the significance that "NIH and NLM are non-profit institutions, devoted solely to the advancement and dissemination of medical knowledge which they seek to further by the challenged practices, and are not attempting to profit or gain financially by the photocopying ... the medical researchers who have asked these libraries for the photocopies are in this particular 
much more recently in a case in which the facts indicated an otherwise uncompelling fair use assertion, the non-commercial educational purpose of library distribution was found by the 10th Circuit Court of Appeals to be "at the heart of the protection of fair use." 80

Courts have often considered the broader public benefit of the use as well, ${ }^{81}$ favoring uses that "typically involve[] the development of art, science, and industry." 82 CDL contributes substantial broad benefits to public knowledge by allowing the public, for the first time, to access particular materials digitally. For public libraries, especially when these collections have been purchased by tax dollars, it is in the public's best interest to have modern access to these works, which were purchased for their benefit.

In summary, we view the purpose and character of the use for CDL to be favored because the purpose is aligned with the principles of another statutory exception (section 109), while the use itself is temporary, non-commercial and leading to important public benefits in research and learning.

\section{Concerns}

Our goal with this paper is to give libraries and their counsel as complete a view of the law regarding CDL as we can. So, it's fair to note a couple of points of concern under the first factor analysis. The first is, despite the strong trend found in the above cases favoring library and educational use, there are a limited number of library fair use cases from which to draw guidance. These include some cases involving academic or scholarly uses in which courts have held that the first factor did not favor the use. ${ }^{83}$ Although libraries rely on fair use routinely, the small number of cases means that when applying a doctrine based

case (and ordinarily) scientific researchers and practitioners who need the articles for personal use in their scientific work... On both sides-library and requester-scientific progress, untainted by any commercial gain from the reproduction, is the hallmark of the whole enterprise of duplication. ... This is important because it is settled that, in general, the law gives copying for scientific purposes a wide scope." $I d$.

80 Diversey v. Schmidly, 738 F.3d 1196, 1203 (10th Cir. 2013) (ultimately concluding that the reproduction and distribution of a confiscated, unpublished dissertation by university officials was not fair use).

81 Sega Enters. Ltd. v. Accolade, Inc., 977 F.2d 1510, 1523 (9th Cir. 1992).

82 Sundeman v. Seajay Socy., Inc., 142 F.3d 194, 203 (4th Cir. 1998) (citing Rosemont Enters., Inc. v. Random House, Inc., 366 F.2d 303, 307 (2d Cir.1966)).

83 Weissmann v. Freeman, 868 F.2d 1313, 1324 (2d Cir. 1989) (professors' verbatim copying of an academic work was not fair use, partly because "the profit/nonprofit distinction is context specific, not dollar dominated"; a professor can "profit" through citation and enhanced academic reputation); see also Worldwide Church of God v. Philadelphia Church of God, Inc., 227 F.3d 1110, 111718 (9th Cir. 2000). 
on caselaw development, there is some uncertainty. This is a general caution, and could be said for any new application of fair use to library practice. ${ }^{84}$ Further, in many ways this is a testament to the low level of risk libraries generally face; libraries seldom attract lawsuits, and on CDL specifically, there are no lawsuits that reflect negatively on the core principles of CDL.

The second and more considerable point of concern is that CDL is not clearly transformative. In recent years, U.S. courts have focused increasingly on whether an alleged fair use is "transformative, 85 " which is, if it "adds something new, with a further purpose or different character, altering the first with new expression, meaning or message." 86 Use of a quotation from an earlier work in a critical essay to illustrate the essayist's argument is a classic example of transformative use. In mass digitization cases involving books-Google Books and HathiTrust, for example - courts have largely focused on how those projects enabled transformative access to information by enabling text search, as well as research uses such as text and data mining.

However, even if CDL is not transformative, ${ }^{87}$ we believe the purpose and character still strongly weighs in favor of a fair use finding. The courts have been clear that " $[\mathrm{w}]$ hile a transformative use is generally more likely to qualify as fair use, 'transformative use' is not absolutely necessary for a finding of fair use.'"88 In HathiTrust, for example, the Second Circuit found that libraries providing fulltext access to print-disabled users was not transformative. 89 "The Authors state that they 'write books to be read (or listened to).' . . By making copies available in formats accessible to the disabled, [HathiTrust] enables a larger audience to read those works, but the underlying purpose of [HathiTrusts's] use is the same as the authors original purpose." 90

Nevertheless, the court concluded that that the use was fair, and favored under the first fair use factor in part because of is alignment with other

84 See Pamela Samuelson, Unbundling Fair Uses, 77 FordHAm L. Rev. 2537, 2580 (2009) (reviewing the bulk of fair use caselaw to date and observing that " $\mathrm{t}]$ here is relatively little caselaw on fair use in educational or research settings.").

85 See Patricia Aufderheide \& Peter Jaszi, Reclaiming Fair Use 86-98 (2d Ed. 2018) (describing ascendancy of the transformative use analysis).

86 Campbell v. Acuff Rose Music, Inc., 510 U.S. 569, 579 (1994).

87 There was no agreement among the Statement drafters on this point, which is why it takes no position on this matter.

88 Authors Guild, Inc. v. HathiTrust, 755 F.3d 87, 102 (quoting from Swatch Grp. Mgmt. Servs. Ltd. v. Bloomberg L.P., 756 F.3d 17, 84 (2d Cir. 2014) and Campbell, 510 U.S. at 579).

89 HathiTrust, 755 F.3d at 101.

${ }^{90} \mathrm{Id}$. 
statutorily favored purposes under Section 121. The court in Swatch similarly expressed doubts about whether the use was transformative, but nevertheless concluded that the public benefit and information dissemination purposesaligned as the Court noted with SEC regulatory guidance - was a favored purpose. ${ }^{91}$

HathiTrust is particularly instructive for CDL because like HathiTrust, the use here is aligned with other Congressionally-sanctioned information policies, the use is non-commercial, and it is aimed at opening up access to readers for research and learning purposes. "Transformative use" is a critical part of the fair use assessment, but is not necessary. Indeed, the vast majority of routine academic, educational, and personal study uses are likely not transformativemultiple copies made for classroom use, reproductions of a work for home study, replication of a work into a different format for later consultations - they all happen in large numbers every day and are in most cases not "transformative" but nonetheless permissible. In cases such as with CDL, where the purpose of the use so well aligns with the overall purposes of the Act, transformative use considerations should not override.

\section{B. The Nature of the Work}

The second fair use factor, "the nature of the copyrighted work," has rarely played a significant role in the overall fair use assessment. Several recent cases have explicitly denied its significance, finding variously that it may be "of limited usefulness," 92 is "rarely found to be determinative," 93 and is "of relatively little importance" in the case at hand. ${ }^{44}$ Traditionally, however, courts have used the second factor to examine whether the work used falls at the "core of intended copyright protection" 95 or closer to its fringes. Use of works of a more scientific or scholarly nature have weighed in favor of fair use; 96 "the law generally

${ }^{91}$ Compare Swatch Group Mgt. Servs Ltd. v. Bloomberg L.P., 742 F.3d 17, 29 (2d Cir. 2014) (Bloomberg did not transform Swatch's work), amended and superseded by Swatch Group Mgt. Services Ltd. v. Bloomberg L.P., 756 F.3d 73, 85 (2d Cir. 2014) (Swatch's use gave it an “arguably transformative" character).

92 HathiTrust, 755 F.3d at 98.

${ }_{93}$ Id. at 102 (quoting Davis v. Gap, Inc., 246 F.3d 152, 175 (2d Cir.2001).

${ }^{94}$ Cambridge Univ. Press v. Patton, 769 F.3d 1232, 1270 (11th Cir. 2014).

95 Campbell v. Acuff-Rose Music, Inc., 510 U.S. 569, 586 (1994).

${ }^{96}$ Am. Geophysical Union v. Texaco Inc., 60 F.3d 913, 925 (2d Cir. 1994) (use of scientific journal articles was favored under the second factor); Penelope v. Brown, 792 F. Supp. 132, 137 (D. Mass. 1992) (use of scholarly work favored); Cambridge Univ. Press v. Patton, 769 F.3d 1232, 1270 (11th Cir. 2014) (informational educational works may be favored for use under second factor, but one 
recognizes a greater need to disseminate factual works than works of fiction or fantasy." 97 Use of works that incorporate significant unprotectable elements is also favored..$^{98}$ Courts have found that the second factor weighs against the use for unpublished works for which the owner intentionally withheld publication in anticipation of some later public release. Use in those cases risks undercutting the economic incentives that are at the core of the copyright system by allowing others to scoop the initial publication of the work. Similarly, courts have found that use of out-of-print works that are unavailable in the marketplace would tend to weigh in favor of the use under the second factor. ${ }^{99}$

For CDL, application of the second factor in the abstract is difficult. Library collections include a wide variety of works for which CDL may be used, some of which will fare more or less favorably under the second factor. Given the limited usefulness of this factor in the overall fair use assessment, we do not believe the nature of the work should be determinative. Nevertheless, some considerations about the nature of the selected works may be helpful for libraries that seek to bolster their overall fair use assertion. These considerations may include applying CDL to works that are out of print, either in print or digitally; of a scholarly or scientific nature, as opposed to popular literature or fiction works; compilations of data (e.g., city directories); works with significant unprotectable elements (e.g., genealogical materials). We offer some operational suggestions about these practices in Part IV of this paper.

\section{The Amount and Substantiality of the Work Used}

The third factor looks at the "amount and substantiality of the work used." More than any other factor, the assessment under the third factor has tended to gravitate toward numerical guidelines, though courts have shunned their use. ${ }^{100}$ The clear implication is that the more content of the original used, the less likely

should look closely at "evaluative, analytical, or subjectively descriptive material" in such a work which may rebalance the second factor either neutrally or against the use).

97 Harper \& Row Publishers, Inc. v. Nation Enterprises, 471 U.S. 539, 563 (1985).

98 Sega Enterprises Ltd. v. Accolade, Inc., 977 F.2d 1510, 1526 (9th Cir. 1992).

${ }^{99}$ Harper $\mathcal{E}$ Row, 471 U.S. at 553 ("If the work is 'out of print' and unavailable for purchase through normal channels, the user may have more justification for reproducing it.") (quoting $S$. Rep. No. 94-473, at 64 (1975)); Hofheinz v. A \& E Television Networks, 146 F. Supp. 2d 442, 447-48 (S.D.N.Y. 2001) (use of trailer for a film released nearly 50 years earlier and not available on the market was favored under the second factor); Maxtone-Graham v. Burtchaell, 803 F.2d 1253, 1264 n.8 (2d Cir. 1986) ("[a] key, though not necessarily determinative, factor in fair use is whether the work is available to the potential user"); Peter Letterese $\mathcal{E}$ Assocs., Inc. v. World Inst. of Scientology Enters., 533 F.3d 1287, 1313-14 (11th Cir. 2008). But see Basic Books, Inc. v. Kinko's Graphics Corp., 758 F. Supp. 1522, 1533 (S.D.N.Y. 1991).

100 Cambridge Univ. Press v. Patton, 769 F.3d 1232, 1272 (11th Cir. 2014). 
the use is to be fair; lengthier reuse would tend to compete with the original. However, courts have clearly tied the assessment under the third factor to the purpose and character assessment. ${ }^{101}$ Courts held on many occasions that use of an entire work, when necessary to fulfill a valid purpose, does not weigh against the use. ${ }^{102}$ What matters is how the amount used aligns with an acceptable purpose under the first factor. "The extent of permissible copying varies with the purpose and character of the use."103

For CDL, the purpose of the use is to enable full-text access to books, so readers can read them online. Arguably, that means the entire work is used. However, CDL does place limits on use of the work; it imposes temporal limits on use (loans are not indefinite) and calls for technological controls on copying that limit further dissemination. These limitations are in many ways similar, for example, to situations in which search engines have been found to have made fair use with low-resolution images. ${ }^{104}$ Technical restrictions on reuse of the files limit their ability to be reused for purposes beyond those intended by the lending library. So, the third factor should be neutral or weigh in favor of the use because copying the entire work is necessary for the purpose of lending, and controls on reuse effectively place limitations on the "amount" of the work the user obtains access to.

101 Authors Guild, Inc. v. HathiTrust, 755 F. 3d 87, 96 (2d Cir. 2014) ("In weighing this factor, we assess the quantity and value of the material used and whether the amount copied is reasonable in relation to the purported justification under the first factor.").

102 See, e.g., Sony Corp. of America v. Universal City Studios, Inc., 464 U.S. 417, 460 (1984) ("the fact that the entire work is reproduced ... does not have its ordinary effect of militating against a finding of fair use"); Bouchat v. Baltimore Ravens Ltd. Partn., 737 F.3d 932, 943 (4th Cir. 2013), as amended (Jan. 14, 2014) (use of entire work allowable to achieve permissible purpose); A.V. ex rel. Vanderhye v. iParadigms, LLC, 562 F.3d 630 (4th Cir. 2009); Chicago Bd. of Educ. v. Substance, Inc., 354 F.3d 624, 629 (7th Cir. 2003) ("there is no per se rule against copying in the name of fair use an entire copyrighted work if necessary"); Sundeman v. Seajay Socy., Inc., 142 F.3d 194, 206 (4th Cir. 1998) (amount and substantiality factor weighed in favor when copy provided to researcher was complete copy because for her scholarly work she "needed access to either the original or an entire copy").

103 Campbell v. Acuff-Rose Music, Inc., 510 U.S.569, 586-87 (1994).See also Bill Graham Archives v. Dorling Kindersley Ltd., 448 F.3d 605, 613 (2d Cir. 2006) (finding the third factor favored the use when displaying "reduced versions of the original images and intermingled these visuals with text and original graphic art." "[C]ourts have concluded that [copying an entire work] does not necessarily weigh against fair use because copying the entirety of a work is sometimes necessary to make a fair use of the image. ... Adopting this reasoning, we conclude that the third-factor inquiry must take into account that the "the extent of permissible copying varies with the purpose and character of the use.").

104 See Perfect 10, Inc. v. Amazon. com, Inc., 508 F. 3d 1146 (9th Cir. 2007); Kelly v. Arriba Soft Corp., 336 F. 3d 811 (9th Cir. 2003). 


\section{Market Harm}

The fourth fair use factor is tied closely together with the first factor analysis. It asks courts to examine "whether the copy brings to the marketplace a competing substitute for the original, or its derivative, so as to deprive the rights holder of significant revenues because of the likelihood that potential purchasers may opt to acquire the copy in preference to the original."105 The fourth factor analysis looks at "not only the ... market harm caused by the particular actions of the alleged infringer," but also the market harm that would result from "unrestricted and widespread conduct of the [same] sort."106

In conducting the analysis, courts have looked at not only market effects for the particular work in the format used, but also at effects on the much broader set of potential licensing markets that may have been usurped by the use. ${ }^{107}$ The scope of the relevant licensing markets is not unlimited, however. Courts have acknowledged that examining licensing markets introduces a degree of circularity; in theory the fact that a use was made at all indicates a potential licensing market that the rightsholder could have exploited. So, courts have limited the analysis to only licensing markets that are "traditional, reasonable, or likely to be developed."108

Like the first factor analysis, the fourth factor is at its core tied back to the underlying purpose of the copyright system; when examining potential market substitution, the question is would the use "cause substantial economic harm such that allowing it would frustrate the purposes of copyright by materially impairing [the rightsholders'] incentive to publish the work?"109

For CDL, the primary reason why the market harm factor weighs in favor of the use is because the market effect of CDL is nearly identical to the market effect already favored under the first sale doctrine. For the works at issue, the controls that CDL requires ensure that the use closely matches the market effect that the rightsholder was already compensated for upon first sale of the book. A secondary consideration, but one that we feel is powerful and where the case for CDL is strongest, that at least for the $20^{\text {th }}$ Century books which make up the bulk

105 Authors Guild v. Google, Inc., 804 F.3d 202, 223 (2d Cir. 2015).

106 Campbell, 510 U.S. at 590 (internal quotation marks and alteration omitted).

107 Bill Graham Archives, 448 F.3d at 614.

108 Am. Geophysical Union v. Texaco Inc., 60 F.3d 913, 930 (2d Cir. 1994) (“It is indisputable that, as a general matter, a copyright holder is entitled to demand a royalty for licensing others to use its copyrighted work, and that the impact on potential licensing revenues is a proper subject for consideration in assessing the fourth factor.").

109 Cambridge Univ. Press v. Patton, 769 F.3d 1232, 1276 (11th Cir. 2014). 
of materials that would benefit from CDL, there is not a functioning market in place to be harmed.

\section{The "First Sale" Market Effect}

The "market harm" analysis is tied closely together with assessment of the purpose of the use under the first factor, informing how courts should view the market purportedly being harmed in connection with the one(s) a copyright owner intends to enter and has a right to control. For example, the Copyright Act does not grant a copyright owner the right to control negative commentary or criticism of its work, 110 uses favored under the first factor. If criticism results in lost sales, is not the type of harm recognized under the fourth fair use factor.

The first sale doctrine itself is intended as a limit on the scope of markets that rightsholders can control. After the "first sale" of the work, rightsholders may no longer place controls on resale, lending, or other restraints on alienation of copies transferred. ${ }^{111}$ So, while CDL may have some effect on a potential market for the work - a user may theoretically borrow a digital copy that is derived from one purchased in print by a library rather than pursue the rightsholder to purchase a digital license-such uses are within the balance of use rights granted to owners of copies. Thus, CDL does not negatively affect the market any differently than the uses already permitted by libraries when lending books physically.

The six controls identified in the CDL Statement identify specifically the ways in which CDL achieves the same market effect that physical "first sale" transactions do. The first two controls are that libraries should (1) "ensure that original works are acquired lawfully," and (2) "apply CDL only to works that are owned and not licensed" meaning that books must have been lawfully acquired and not subject to additional restrictions, just as a library would be required to lawfully acquire a physical book - typically, through a purchase in which the rightsholder is compensated - so would a library engaging in CDL be required to ensure the same.

110 Campbell, 510 U.S. at 590.

111 See, e.g., Disney Enterprises, Inc. v. Redbox Automated Retail, LLC, CV 17-08655 DDP (AGRx), 2018 WL 1942139, at *6 (C.D. Cal. Feb. 20, 2018) (“Disney's copyrights do not give it the power to prevent consumers from selling or otherwise transferring the Blu-ray discs and DVDs contained within Combo Packs. Disney does not contend otherwise. Nevertheless, the terms of both digital download services' license agreements purport to give Disney a power specifically denied to copyright holders by $\S 109$ (a). RedeemDigitalMovies requires redeemers to represent that they are currently "the owner of the physical product that accompanied the digital code at the time of purchase," while the Movies Anywhere terms of use only allow registered members to "enter authorized ... Digital Copy codes from a Digital Copy enabled ... physical product that is owned by [that member]."). 
The third and fourth CDL controls are that libraries should (3) "limit the total number of copies in any format in circulation at any time to the number of physical copies the library lawfully owns (maintain an "owned to loaned" ratio)," and (4) "lend each digital version only to a single user at a time just as a physical copy would be loaned." These controls ensure that libraries lending digital copies don't get more than what they bargained for. A library that owns a single copy of a book could only lend a single copy out at a time. If the digital version is checked out and viewed by a patron, the corresponding physical version must be restricted and controlled (e.g., placed in locked stacks or taken out of circulation entirely). Likewise, mimicking the restraints on physical materials in which only one user can typically check out and read a physical book at a time, only one user would be permitted to check out and read the digital book at any given time.

Finally, the fifth and sixth controls are that libraries should (5) "limit the time period for each lend to one that is analogous to physical lending," and (6) "use technical restrictions to prevent copying and redistribution." Those controls, especially the deployment of DRM, ensure that just as with physical books, the digital copies are effectively still in control of the library and cannot (without illegal action on the part of the user) proliferate into additional copies.

From a single transaction standpoint, the library making the CDL use must still have acquired legitimately the book in physical format before lending. What CDL does is allow a change of the format in which that lend is made. When the digital copy is being read by a patron, however, the physical copy is restricted and unavailable for consultation, so there is no situation in which the library is getting use of two copies for the price of one. Similarly, for the aggregated effect question - what if everyone did it? - the analysis is not radically different; any library engaging in CDL would still be required to own a copy of the work, meaning that the market effect would look roughly the same.

We acknowledge that these controls do not address the full range of market concerns raised by others. In the context of broader debates about digital first sale, the primary objections raised by rightsholders were related to market disruption. The two primary collections of these objections are the 2001 U.S. Copyright Office report addressing digital first sale, and a similar and updated 2016 U.S.P.T.O report. ${ }^{112}$ In their respective context, both reports were intended to advise Congress on whether to pass new legislation specifically enacting a new digital first sale law. And, in the few cases where these issues have been raised in litigation (most recently in cases involved $\mathrm{mp} 3$ sales and streaming

\footnotetext{
112 DMCA SECTION 104 REPORT, supra note 11; USPTO FIRST SALE STUDY, supra note 29.
} 
videos) courts have found it necessary to address the issues raised in those reports. ${ }^{113}$

Those reports raise three additional concerns that may differentiate digital lending from physical lending, that: 1) digital distribution eliminates transactional friction inherent in physical loans; 2) digital copies don't degrade like physical works; and 3) digital distribution raises security and piracy risks. We address each below. Ultimately, we conclude that none should pose an obstacle to well-designed controlled digital lending system. While we do not believe libraries implementing CDL must respond to these concerns, a conservative CDL system may take these factors into account. We identify ways to do so in Part IV of this paper.

\section{a) "Digital distribution eliminates transactional friction inherent with physical loans."}

Movement of a copy from one location to another takes time; vehicles must drive and deliver copies, acting as a "natural brake on the effect of resales on the copyright owner's market." 114 For libraries, it takes time for returned books to make their way back on to shelves, and to check them out again to the next patron. For loans out to patrons in other locations, interlibrary loan adds an additional layer of delay. For digital transactions factors such as time and space no longer act as major impediments to transfer. The question is, should they, in order to more closely mimic the physical lending environment that exists with print?

By its terms, the Copyright Act does not grant rightsholders a right to transactional friction, nor does the Copyright Act freeze in time the historical conditions under which copies are bought and sold or lent. Amazon has dramatically altered the used book market, removing barriers to the flow of those books. Amazon (or libraries) using drones to deliver physical books to one's doorstep yet faster is no less an impingement on a rightsholder's market than a digital transaction that moves a copy yet more quickly. Such advancements have already occurred; advances in interlibrary loan services such as RapidILL and BorrowDirect mean books now move quickly and seamlessly between libraries in dramatically less time than in the 1970s when the Copyright Act was enacted. ${ }^{115}$ Certainly other actors - FedEx, the fuel suppliers, physical book

113 Capitol Records, LLC v.ReDigi Inc., 934 F. Supp. 2d at ; Disney Enters. Inc. v. Redbox Automated Retail LLC, No. 17-CV-8655, 2018 WL 1942139, at *7-9 (C.D. Cal. Feb. 20, 2018).

114 DMCA SECTION 104 REPORT, supra note 11, at 83.

115 See RapidILL, http://rapidill.org/ (last visited September 14, 2018); BorrowDirect, http:// www.borrowdirect.org/ (last visited September 14, 2018) (3-5 day delivery for materials across a federated catalog of 90 million plus volumes from the Ivy Plus libraries). 
inventory system manufacturers - may suffer with digital lending. But those markets do not belong to the copyright holder.

We do acknowledge, however, that the first sale doctrine was developed by the courts and embraced by Congress in the context of a physical environment where transaction costs were high. The USPTO in its recent white paper declining to recommend development of a broad conception of "digital first sale" stated that that " $[\mathrm{t}] \mathrm{o}$ the extent that library lending involves library patrons 'willing and able to wait their turn for the limited loans and use of library materials,' [ ] the inefficiencies built into lending processes may avoid crossing the line of competing with the commercial market."116 So, while transactional friction may not be necessary for CDL, an implementation that added it could reduce risk for libraries.

\section{b) "Digital copies don't degrade like physical works."}

A second, broader, market harm concern is that digital works don't degrade like physical works. With that argument is the implicit suggestion that, like the friction discussed above, degradation was implicitly calculated into the balance of rights Congress arrived at when codifying the first sale doctrine. For one, this argument fails to appreciate that for long-term digital copies do degrade and require significant effort to maintain. ${ }^{117}$ Redundancy is a standard requirement for the preservation of digital copies, requiring multiple storage locations, the technology of which needs to be upgraded and replaced every few years. Systems need to be migrated periodically, and platforms updated to interact with current technology. HathiTrust, for example, reports replacing storage hardware every 3-4 years. ${ }^{118}$ All are potential failure points at which the particular copy of the work can degrade, sometimes spectacularly. So, the stored digital copy used for lending does degrade over time and in reaction to use, just in ways that are not entirely analogous to the more gradual and straightforward entropy of the physical book.

Those facts aside, to our knowledge no court has ever tied the application of the first sale doctrine to a required, planned degradation of the format in which the copy exists. Libraries can lend brand new books in perfect condition just as they can older, tattered ones, many of which are repaired and rebound by library

116 USPTO FIRST SALE STUDY, supra note 29, at 70.

117 See, e.g., Bairavasundaram, Lakshmi N., Andrea C. Arpaci-Dusseau, Remzi H. ArpaciDusseau, Garth R. Goodson, and Bianca Schroeder, An Analysis of Data Corruption in the Storage Stack, ACM TRANSACTIONS ON STORAGE (TOS) 4, no. 3 (2008): 8, DOI: 10.1145/1416944.1416947 ("An important threat to reliable storage of data is silent data corruption.").

118 HathiTrust Trustworthy Repository Audit and Certification (TRAC), HATHITRUST.ORG (2011), https://www.hathitrust.org/trac. 
staff or volunteers. Since the first recognition of the first sale doctrine over 100 years ago, the advent of acid-free paper, improved binding technology, media such as microform and magnetic tape and other innovations have extended the life of physical works dramatically. ${ }^{119}$ In that time neither Congress nor the courts have altered the balance of rights in response to degradation. What's more, libraries engage in systematic preservation and conservation work to prevent or stop degradation. Driven in part by a lack of market availability, libraries repair, strengthen, and rebind many books in their collections, in large part because replacements cannot be purchased. ${ }^{120}$ So as applied to CDL, we don't find degradation as a distinctive digital feature to be a compelling point. The idea has no connection to the statutory or judicial development of the rationale for first sale, and it fails to account for how digital storage and transmission do encounter degradation that is consistent with (if not more severe than) physical degradation.

\section{c) "Digital distribution raises unique security and piracy risks"}

Finally, the third market-harm concern is that digital distribution raises greatly increased risks of piracy. In its 2001 report addressing digital first sale, the U.S. Copyright Office concluded that "the concerns about expanding first sale to limit the reproduction right, harm to the market as a result of the ease of distribution, and the lessened deterrent effect of the law that could promote piracy, outweigh the pro-competitive gains that might be realized from the creation of a digital first sale doctrine."121 In its 2016 White Paper addressing digital first sale, the USPTO noted similar concerns. ${ }^{122}$ The argument is that digital distribution is inherently more prone to negative market effects through

119 See, Library of Congress, The Deterioration and Preservation of Paper: Some Essential Facts (n.d.), http://www.loc.gov/preservation/care/deterioratebrochure.html ("If mass deacidification treatment is carried out while the paper still has significant measurable strength, and the treated items are then stored under proper conditions, these once-acidic items are projected to remain in usable condition for several centuries, rather than becoming brittle and unusable in only fifty to one hundred years.").

120 For example, in one recent survey with just 69 responding institutions, the Association for Library Collections \& Technical Services found that respondents provided conservation treatment of a variety of levels to over 200,000 volumes of books and bound volumes. See ALCTS, Annie Peterson, Holly Robertson, and Nick Szydlowski, Preservation Statistics Survey Report FY2015 (2016),

http://www.ala.org/alcts/sites/ala.org.alcts/files/content/resources/preserv/presstats/FY201 5/FY2015PreservationStatistics.pdf.

121 DMCA SECTION 104 REPORT, supra note 11 ("Asserting, by analogy, that an online digital transmission is the same as a transfer of a material object ignores the many differences between the two events. Digital transmission has a much greater effect on the market for copies provided by the copyright owners. It is also accompanied by a greatly increased risk of piracy.").

122 USPTO FIRST SALE STUDY, supra note 29, at 51. 
piracy because works can be copied and distributed with ease. Courts have taken security concerns seriously. In Authors Guild v. HathiTrust, for example, the Second Circuit gave considerable attention to the security precautions HathiTrust had put into place for the digitized volumes in its collection. ${ }^{123}$

Digital distribution of copyrighted works is exceedingly common. For CDL, we see the risks as no greater than any other digital transaction. Publishers regularly license electronic books for digital distribution without any discernable market premium added to account for the additional risk of impermissible downstream copying. For libraries, security issues should be taken seriously, which they are by design through the six CDL controls described above. Like the approach taken by HathiTrust, the repository of digital copies must be secured from unintended access. Going even beyond the HathiTrust case, CDL would require physical access to works be restricted as well, while digital copies are lent. In addition, the files lent must be controlled in some significant way (e.g., using DRM) that will prevent the patron from retaining perpetual or unrestricted access to the file. Other digital first sale scenarios that involve permanent transfer of files from one party to another, such as sale of $\mathrm{mp3s}$, have struggled with how to effectively implement "forward-and-delete" technology. ${ }^{124}$ For libraries lending works, the solution is potentially much easier; lending technology for distribution of licensed e-books is well established. Many publishers use and are comfortable with security implemented through systems like Overdrive, or using Adobe Digital Editions. For CDL, the most effective and defensible approach may be to use those very same copy and piracy controls that publishers themselves employ for distribution of their licensed e-book content.

\section{Market Failure for $20^{\text {th }}$ Century Books}

Finally, a secondary but important reason why CDL would fare well under the market harm analysis is because it addresses a broad market failure, particularly with respect to the $20^{\text {th }}$ century books that are generally not available in digital formats. It's precisely the kind of consideration fair use is equipped to address. ${ }^{125}$ While we believe CDL has broader applications than just to these books, the significance of the market failure is so severe that we believe it

123 Authors Guild, Inc. v. HathiTrust, 755 F.3d 87, 100 (2d Cir. 2014).

124 Capitol Records, LLC v. ReDigi Inc., 934 F. Supp. 2d 640, 645 (S.D.N.Y. 2013).

125 The seminal article on fair use addressing market failure was written by Wendy Gordon in 1982, sparking a wave of scholarship on the ways in which fair use may take into account ideas of market failure both generally and for specific use cases (e.g., parody). Wendy Gordon, Fair Use as Market Failure: A Structural and Economic Analysis of the Betamax Case and its Predecessors, 82 Colum. L. ReV. 1600 (1982). 
deserves special consideration. For these $20^{\text {th }}$ century books, we believe the fair use argument is strongest.

The most significant market failure for these books is with truly orphaned works - i.e., books for which the rightsholder cannot be identified or located after a diligent search. ${ }^{126}$ For those works, market failure is confirmed through the diligent search, which demonstrates the insurmountable transaction costs just in searching for the rightsholder. But the $20^{\text {th }}$ century book market suffers from market failure even when owners are known. Failure of rightsholders to exploit the e-book market likely has many causes. Some of those are production-related transaction costs, some are due to the complex thickets of rights associated with each work, ${ }^{127}$ and some are likely due just to competing priorities. In all such cases, books are not commercially available in digital form. High transaction costs make it economically unviable for a willing rightsholder and a willing user to negotiate for a sale.

The Copyright Act does not require rights holders to sell their works in the marketplace; they do not face a "use it or lose it" regime of protection. ${ }^{128}$ Beyond the threshold question of protection, even within the fair use analysis, courts have found valid reasons why market harm analysis should weigh against the use when the copyright owner may have had creative or economic reasons for holding back the work. ${ }^{129}$ Yet, courts have held that failure to exploit the market can be evidence of lack of market harm under the fourth fair use factor. For example, in Cambridge University Press v. Patton, a group of publishers sued Georgia State University, claiming that university-uploaded excerpts of books to

126 See Jennifer Urban, How Fair Use Can Help Solve the Orphan Works Problem, 27 BerKeLEY TECH. L.J. 1379, 1404 -09 (2012).

127 See Pamela Samuelson, Google Book Settlement as Copyright Reform, 2011 WISC. L. REV. 479, 495-99 (identifying uncertainty over ownership of e-book rights as contributing to the development of the Google Books Search Settlement, which have provided e-access to millions of books). See also Random H., Inc. v. Rosetta Books LLC, 150 F. Supp. 2 d 613 (S.D.N.Y. 2001), aff'd, 283 F.3d 490 (2d Cir. 2002) (resolving contractual dispute between publisher and author over ownership of e-book rights).

${ }^{128}$ Nor must copyright owners sue for each infringement. For example, in concluding that the doctrine of laches is rarely available to copyright defendants, the Supreme Court in Petrella $v$. Metro-Goldwyn-Mayer, Inc. explained: "If the rule were, as MGM urges, 'sue soon, or forever hold your peace,' copyright owners would have to mount a federal case fast to stop seemingly innocuous infringements, lest those infringements eventually grow in magnitude." The Copyright Act's statute of limitations and accrual rules "avoids such litigation profusion. It allows a copyright owner to defer suit until she can estimate whether litigation is worth the candle." 134 S. Ct. 1962, 1976 (2014).

129 Balsley v. LFP, Inc., 691 F.3d 747, 761 (6th Cir.2012) ("current desire or ability to avail themselves of the market" was irrelevant to the question of potential market harm); Castle Rock Entm't, Inc. v. Carol Publ'g Grp., Inc., 150 F.3d 132, 145-46 (2d Cir.1998) (finding market harm and noting that "copyright law must respect that creative and economic choice"). 
the course e-reserves practices constituted copyright infringement. ${ }^{130}$ For many of those excerpts, the publishers failed to make licenses for electronic copies available. The Eleventh Circuit found this significant in weighing the fourth factor:

...if a copyright holder has not made a license available to use a particular work in a particular manner, the inference is that the author or publisher did not think that there would be enough such use to bother making a license available. In such a case, there is little damage to the publisher's market when someone makes use of the work in that way without obtaining a license, and hence the fourth factor should generally weigh in favor of fair use. ${ }^{131}$

In so concluding, the Eleventh Circuit framed its analysis in terms of the incentive effects of copyright; in this case, whether allowing the use would "frustrate the purposes of copyright by materially impairing Defendant's incentive to publish the work." 132 The Supreme Court has endorsed that approach:

... $[\mathrm{t}]$ he purpose of copyright is to create incentives for creative effort. Even copying for noncommercial purposes may impair the copyright holder's ability to obtain the rewards that Congress intended him to have. But a use that has no demonstrable effect upon the potential market for, or the value of, the copyrighted work need not be prohibited in order to protect the author's incentive to create. The prohibition of such noncommercial uses would merely inhibit access to ideas without any countervailing benefit. 133

\footnotetext{
130 Note that in Cambridge Univ. Press v. Patton, the district court found fair use even where the excerpts were distributed with no control over the physical original nor any limitation on the number of students who could view the copy at any given time, making the market effect potentially more severe than what would be experienced with CDL. 769 F.3d 1232 (11 ${ }^{\text {th }}$ Cir. 2014).

${ }^{131} \mathrm{Id}$. at 1277. Untapped markets have been cited as persuasive evidence of no or minimal market harm in other cases as well. Sony Corp of Am. v. Universal City Studios, Inc., 464 U.S. 417, 451-55 (1984) (no market for home video recording for time-shifting); Kelly v. Arriba Soft Corp., 336 F. 3d 811, 821-22 (9th Cir. 2002); Field v. Google Inc., 412 F. Supp. 2d 1106, 1122 (D. Nev. 2006) (no evidence a "market for licensing search engines to access Web pages through 'cached' links"). See also Campbell v. Acuff-Rose Music, Inc., 510 U.S. 569, 592 (1994) (market for licensing critical commentary of copyrighted work is unlikely).

$132 \mathrm{Id}$. at 1276.

133 Sony Corp. of Am. 464 U.S. at 450-51. For large numbers of books in research libraries, the incentives of U.S. copyright protection played no role in their creation. Millions were in the public domain immediately upon publication until that public domain status was rescinded many years later under the Uruguay Round Agreements Act. 17 U.S.C. § 104A (2018).
} 
For print-only books, the potential e-book market has been available for nearly 20 years. Publishers have by and large not exploited that market, for various reasons. Libraries and readers have been waiting, ${ }^{134}$ but at this point it cannot be said to be a "reasonable, or likely to be developed"135 market.

Publishers have largely not even maintained a print market presence, allowing books to devolve to out-of-print status quickly. Several studies have suggested that copyright may reduce the availability of books generally. ${ }^{136}$

So, for books published in this time period as a whole, there is a strong argument that they collectively represent a market failure. Part of that failure is due to high costs of determining commercial availability for any given work. The costs of searching and identifying which works are out of print, orphaned, or not available in e-book format is costly itself. However, we believe that there is sufficient data for assessment of commercial availability that can be leveraged for CDL to maximize the case that these particular titles within this $20^{\text {th }}$ century focus are unavailable either in print or electronically. Those, we believe, present the very best case for CDL uses.

\section{TAKEAWAYS: SYSTEM DESIGN AND RISK MITIGATION}

Libraries thinking about CDL will encounter risk, both positive and negative. On the positive side, we believe there is a significant upside: CDL helps libraries fulfill their missions in the broadest sense, using technology to increase effective, non-discriminatory access to collections for our users, and the world. Libraries have faced existential challenges for decades - "Is the library dead?" - but have survived in part because of their responsiveness to new technology. As new generations of information consumers expect immediate digital access to collections--along with those who have always needed but not been given digital access - libraries that fail to make their substantial collections available face anew the risk of becoming irrelevant or at least minimally effective in users' eyes. How can we help those users find and use the millions of volumes of the past century

134 See Paul J. Heald, The Demand for Out-of-Print Works and their (Un)Availability in Alternative Markets (Illinois Public Law and Legal Theory Research Papers Series No. 14-31, 2014),

http:/ / papers.ssrn.com/abstract $=2409118$

135 Am. Geophysical Union v. Texaco Inc., 60 F.3d 913, 930 (2d Cir. 1994).

136 William M. Landes \& Richard A. Posner, Indefinitely Renewable Copyright, 70 U. CHI. L. REV. 471,474 (2003)(“[O]nly a tiny fraction of the books ever published are still in print; for example, of 10,027 books published in the United States in 1930, only 174, or 1.7 percent, were still in print in 2001"); Paul J. Heald, How Copyright Keeps Works Disappeared, 11 J. EMPIRICAL L. STUDIES 829, 832 (2014) ("Surprisingly, eBooks do not provide a significant alternative marketplace for out-ofprint books. For example, only 36 percent of 162 bestselling books from 1923-1932 currently had eBook editions in 2014, and only one of the eBooks in that data set represented an out-of-print bestseller."). 
(which makes up the bulk of many library collections) if we cannot get materials to them in the modern (digital) formats they need?

For negative risk, there are three primary types we worry about: 1) the risk that a library is sued in the first place, 2) the risk that the library loses the lawsuit, and 3) the risk of consequences in the face of defeat in a lawsuit. For each aspect of risk, libraries should make an honest assessment of their risk tolerance, accompanied by advice from legal counsel about how to match some of the ideas presented above and below with that risk profile.

For risk of being sued, it's not necessarily about the law itself. The issues are actually about time, resources, and reputational harm in defending a lawsuit. A lawsuit can take a tremendous amount of time. For example, the Georgia State ereserves case (Cambridge University Press $v$. Patton) has now entered its $10^{\text {th }}$ year of litigation. ${ }^{137}$ Lawsuits are rarely resolved in a few months. There can be years of pre-trial action after the complaint is filed. There could be challenges to the pleadings through the motion process, which add additional delay. Answering questions, producing documents, or taking testimony can often take months or years, even before you get to trial. Although the reality is that most lawsuits do not go to trial, ${ }^{138}$ the cost of litigation can be high, and these costs often depend on the issues involved and the location of the trial. Attorneys' fees and costs to go through the process from complaint, right up to trial, can range in the tens of thousands of dollars, and, if it does go to trial, that expense can easily double. ${ }^{139}$

Second, the risk that the library loses in court is primarily addressed by the strength of the legal position under fair use, the framework of which is addressed in Part III. The analysis is also general - case law in particular jurisdictions may be more or less favorable - and it doesn't fully take into account some of the particular facts and design choices (addressed below) that libraries may choose to implement to further enhance their position. And again, we caution that there are no fair use cases that square precisely with this use scenario, and so libraries entering this space must embrace a certain degree of legal ambiguity. But, the analysis above shows that there is a good faith, reasonable basis for concluding that such uses constitute fair uses.

137 Cambridge Univ. Press v. Patton, 769 F.3d 1232 (11th Cir. 2014).

138 "[P]erhaps up to $97 \%$ of cases are resolved by means other than by trial." Barkai, Kent and Martin, A Profile of Settlement, 42 COURT REvIEW: THE JOURNAL OF THE AMERICAN JudGeS ASSOCIATION 34 (2006).

139 See AIPLA, Report Of THE ECONOMIC SuRvey 36; I-175 (2013) (reporting that litigation with less than $\$ 1$ million at stake costs on average around $\$ 150,000$ through the discovery process). While we primarily address risks associated with legal action, CDL may raise many other types of reputational, institutional, and political risks that libraries should carefully consider. 
Finally, there is the question of what happens if the library loses the lawsuit. Typically, the plaintiff would request that the court enter an order for an injunction or damages, or, on occasion, both against the losing party. Statutory damages are the major concern. ${ }^{140}$ Unlike most other jurisdictions, under U.S. law, infringements of works registered with the copyright office (most published books are) can carry a damage award within a statutory pre-set range of up to $\$ 150,000$ per work infringed in cases of willful infringement. ${ }^{141}$

However, for libraries there is some good news to limit risk exposure. First, Congress created a special provision to protect for teachers, librarians, archivists, public broadcasters and the nonprofit institutions with which they are associated from liability when they believed and had reasonable grounds for believing that the use they were making was a fair use. In that case that statute instructs that the court "shall remit statutory damages." 142 Given the public benefit and generally good faith approach to this issue, it's also important that courts, in applying this provision, may avoid "mechanical application of the statutory damage provision of the Copyright Act" when it would "lead[] to absurd results." 143 The statute "provide[s] the courts with reasonable latitude to adjust recovery to the circumstances of the case, thus avoiding some of the artificial or overly technical awards resulting from the language of the existing statute."144

Second, some institutions may benefit from sovereign immunity, a doctrine that protects states from federal court interference, derived in part from the Eleventh Amendment to the United States Constitution. ${ }^{145}$ Eleventh amendment sovereign immunity, though not absolute, shields state actors from damage

140 In the few recent cases litigated against libraries, plaintiffs have not sought statutory damage awards. However, statutory damages award are large and have been awarded in other cases. 17 U.S.C. § 504(c) (setting damage ranges up to $\$ 150,000$ per work infringed).

${ }^{141}$ For CDL, it seems unlikely that a court would find infringement to be "willful."

14217 U.S.C. $\S 504(C)(2)$ (“The court shall remit statutory damages in any case where an infringer believed and had reasonable grounds for believing that his or her use of the copyrighted work was a fair use under section 107, if the infringer was: (i) an employee or agent of a nonprofit educational institution, library, or archives acting within the scope of his or her employment who, or such institution, library, or archives itself, which infringed by reproducing the work in copies or phonorecords; or (ii) a public broadcasting entity which or a person who, as a regular part of the nonprofit activities of a public broadcasting entity (as defined in section 118(f)) infringed by performing a published nondramatic literary work or by reproducing a transmission program embodying a performance of such a work.).

${ }^{143}$ Doehrer v. Caldwell, 1980 U.S. Dist. LEXIS 10713, *2.

${ }^{144}$ Id. (quoting S. Rep. No. 94-473, 94th Cong., 2d Sess).

145 "The Judicial power of the United States shall not be construed to extend to any suit in law or equity, commenced or prosecuted against one of the United States by Citizens of another State, or by Citizens or Subjects of any Foreign State" U.S. CONST. AMEND. XI 
awards in federal court. ${ }^{146}$ Because sovereign immunity limits the judicial power of the federal judiciary under Article III of the Constitution, absent a valid retraction of that sovereign immunity by Congress, "a State will ... not be subject to suit in federal court unless it has consented to suit, either expressly or in the plan of the convention." 147 While Congress has attempted to abrogate states' immunity from liability for federal copyright law violations, ${ }^{148}$ over a dozen cases have found those attempts to be ineffective, including appellate decisions from the Eleventh, Fifth, and most recently the Fourth Circuits. ${ }^{149}$ Sovereign immunity can be an important factor in assessing the risk of adopting a CDL program. Presently, state and tribal governments and their related departments such as state university libraries, museums, or archives, are immune from damage awards. Of course, plaintiffs could still bring a suit. Sovereign immunity also lowers the risk of such a suit because the outcome may have little rewardthere is no money in it for litigants.

While some risks such as exposure to damages may be minimized by sovereign immunity or the statutory damages exception, libraries can also be proactive to minimize risk with CDL by implementing some additional system design and library policies, as well as selecting materials to be lent using CDL with an eye toward risk. We conclude with several practical ideas about how to do so:

\section{A. System Design and Library Policies}

The six basic system design elements identified in the Statement and introduced at the outset of this paper are, we believe, all that are necessary to make a compelling legal case for CDL. 150 There are, however, several other

146 See Nevada v. Hall, 440 U.S. 410, 420 n. 19 (1979).

147 Blatchford v. Native Village of Noatak and Circle Village, 501 U.S. 775, 779 (1991).

148 In 1990, Congress passed the Copyright Remedy Clarification Act (CRCA), 17 U.S.C. § 511, as part of an effort by Congress to attempt to remedy imbalances between private and state institutions caused by Eleventh Amendment sovereign immunity in the intellectual property arena. It declared that "any State, any instrumentality of a State, and any officer or employee of a State or instrumentality of a State acting in his or her official capacity" shall not be immune under either the Eleventh Amendment for violation of the exclusive rights of copyright holders. 17 U.S.C. § 511(a).

149 "We conclude that in enacting the Copyright Remedy Clarification Act, Congress satisfied neither requirement [to abrogate Eleventh Amendment sovereign immunity]." Allen v. Cooper, No. 17-1522, 2018 WL 3352378, at *7 (4th Cir. July 10, 2018); Natl. Ass'n of Boards of Pharm. v. Bd. of Regents of the U. System of Georgia, 633 F.3d 1297 (11th Cir. 2011); Rodriguez v. Texas Commn. on the Arts, 199 F.3d 279 (5th Cir. 2000). See also Issaenko v. U. of Minnesota, 57 F. Supp. 3d 985, 1007 (D. Minn. 2014) (citing a dozen cases).

150 The six design principles state that libraries should: 
design features that may reduce risk and enhance the fair use position, primarily by enhancing the argument that CDL does not pose an undue market harm. These design elements attempt to make CDL mimic even more closely the physical environment and attendant friction reuse, as well as the security limitations that physical lending currently requires.

One way is to introduce additional artificial "friction" into the system, for example, is by extending the time between digital lends, more closely mirroring how physical books are lent and returned. For books that would typically take 24 hours to make their way back on to the shelves after being returned, that might be an appropriate waiting time for digital copies as well. For reserve materials that rapidly move in and out of the shelves with little wait, a shorter period may be appropriate to mimic the realities of a physical lend. Libraries may even want to take in user geography - if a user borrows a book while located further away, add more time in between the next loan than if the user is located next door-or other factors that have historically slowed the flow of physical works.

A conservatively designed CDL system could also introduce characteristics that mimic physical degradation. For example, a library might introduce lending limits based on library experience with physical lending. If a physical book could be expected to circulate 2,000 times before it degrades, the library could place the same limit on circulation of the digital copy. For many books, this could pose little practical challenge. Large research libraries hold many books that have circulated very seldom in print, ${ }^{151}$ and so for many obscure materials ever hitting a maximum loan threshold may be unlikely (though we recognize, digital availability may itself drive lending). For such an implementation, it would be important for libraries to develop good data on how long an average book actually circulated before it degrades to the point it can no longer be used. Library experience and publisher expectations seem to diverge significantly on

(1) ensure that original works are acquired lawfully;

(2) apply CDL only to works that are owned and not licensed;

(3) limit the total number of copies in any format in circulation at any time to the number of physical copies the library lawfully owns (maintain an "owned to loaned" ratio);

(4) lend each digital version only to a single user at a time just as a physical copy would be loaned;

(5) limit the time period for each lend to one that is analogous to physical lending; and

(6) use digital rights management to prevent wholesale copying and redistribution.

151 See Allen Kent et al. Use of Library Materials: The University of Pittsburgh Study (1979) (indicating that fewer than $40 \%$ of books purchased in the preceding 10 years had circulated at all, and predicting that fewer than $2 \%$ ever would); Cornell University Library, Report of the Collection Development Executive Committee Task Force on Print Collection Usage 2 (2010) (approximately 55\% of monographs purchased since 1990 have never circulated). 
this; Harper Collins at one point believed that 26 loans was all that an average book would handle before it degraded, 152 while libraries lending some books (e.g., books placed on reserve) will regularly see lending run into the thousands before degradation occurs.

Libraries may also pay special attention to controlling both digital and physical copies. While all applications of CDL should restrict access to physical copies while the digital is lent, some practical strategies may ensure that such restrictions are especially rigorously followed. For libraries with open stacks, this may mean rapidly removing books from open circulation if they are digitized and lent. For others, a more reliable method may be to only lend books whose physical manifestations are already tightly controlled, either in closed stacks or off-site storage.

Libraries may also limit who they will lend digital copies to as an additional way to limit the overall reach of the copy and therefore the potential market effect. Libraries serve particular communities of users--an academic library primarily serves its students and faculty, a public library serves its local residents - and so the rationale would be that digital lending should be made equivalent to the same group of users who would have access to the physical materials. While many libraries make their collections available broadly to many users, user-group considerations may mean that libraries will want to think carefully about issues such as who their core users are and, for example, how lending to partner libraries in local or regional consortia with deeply integrated print collections may work, as opposed to users at libraries with more distant interlibrary loan arrangements. In any case, the aim would be to make collections more accessible for those who would ordinarily, already be entitled to access.

In addition, libraries may apply more or less restrictive controls on what users can do with copies while they are lent to them. Ordinarily, a borrower of a physical book can make photocopies, scans, or other basic reproductions, usually for private study or minimal further sharing. Practicality usually limits users from reproducing the entire physical work over again. While all CDL systems should implement some type of technological protection measures to prevent wholesale copying, libraries that seek to take a conservative approach to CDL may seek to limit any copying at all, while others may allow users to reproduce or print a small selection from the work.

Finally, libraries may choose to limit access to books based on feedback from rightsholders about specific materials loaned through CDL. While ultimately the

152 Jacket Copy, HarperCollins' 26-checkout Limit on Libraries' Ebooks Starts Today, March 7, 2011, http:/ / latimesblogs.latimes.com/jacketcopy/2011/03/harpercollins-library-ebookcheckout-limit.html. 
rationale for CDL remains the same regardless of a rightsholder objection, libraries may choose to limit risk and exposure to litigation by employing a takedown policy and including in their system design a mechanism for rightsholders to communicate about books that they would prefer not be lent. Many libraries already employ such policies with digitized collections, particularly those that include materials from unknown or unlocatable owners. For CDL, extending those policies may be a natural and simple way to defuse risk before it culminates in a potentially costly dispute.

\section{B. Collection Choices}

The choice in what books are selected for CDL can also play a significant role in risk mitigation. Book candidates with the lowest risk - and the strongest fair use argument, though those analyses are not necessarily tied together-are generally those with the lowest likelihood of market exploitation. Our analysis above pays special attention to 20th century books generally, but there are several subcategories of works that libraries may select for CDL that would yield further reduction of risk.

\section{Old Books and the Public Domain}

There is some practical risk mitigation in selecting older titles for digitization. ${ }^{153}$ In addition to aiding in the likelihood that the market is significantly diminished, many older works may in fact be in the public domain, subject to no copyright restrictions on use at all. Because the public domain analysis can be time consuming and costly, ${ }^{154}$ for libraries that are unable to undertake a full public domain analysis to each work, using older works as a proxy in combination with a CDL strategy may be an effective way to minimize copyright-related risks.

For published books, there are a few ways to approximate which works are more likely to be in the public domain than others. One is to focus on books first published in the United States, since many of the rules that place published

153 There is also a compelling argument that the fair use case should become stronger the further along the work is in its copyright term. See Joseph P. Liu, Copyright and Time: A Proposal, 101 Mich. L. Rev. 409 (2002); Justin Hughes, Fair Use Across Time, 43 UCLA L. Rev. 775 (2003); William F. Patry \& Richard A. Posner, Fair Use and Statutory Reform in the Wake of Eldred, 92 CAL. L. REV. 1639 (2004).

154 For an excellent and thorough guide, see Melissa Levine et al., Finding the Public Domain: Copyright Review Management System Toolkit (2016), https:/ / doi.org/10.18665/sr.289081. 
works into the public domain do not apply to works first published abroad. 155 Another is to focus on books within that subset that were published before 1989, since books published before that date must have complied with U.S. copyright notice requirements (the () on the title page, or similar) to obtain protection. ${ }^{156} \mathrm{~A}$ third is to look at U.S. books only published before 1963. Copyright for U.S. works published before that date must have been renewed with the U.S. Copyright Office to have continued protection. Very few rightsholders filed for renewal. ${ }^{157}$ Finally, a most conservative library might focus just on books in their last 20 years of copyright protection - books published before 1943 - for which the library is willing to do a reasonable investigation to determine if the book is still commercially available. When Congress extended copyright protection by 20 years in the 1998 Copyright Term Extension Act, it granted libraries special rights to use works in that extended term under Section 108(h). ${ }^{158}$

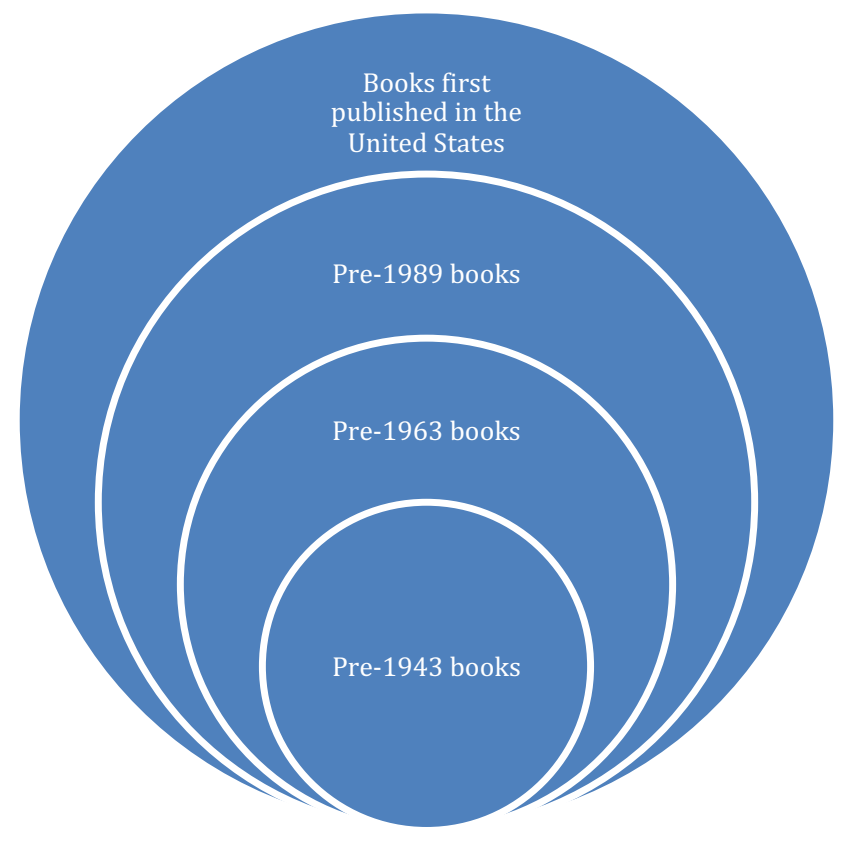

155 See Copyright Term and the Public Domain in the United States, Cornell University Library Copyright Information Center (updated January 10, 2018), https://copyright.cornell.edu/publicdomain.

15617 U.S.C. § 401 (2018); Berne Convention Implementation Act of 1988, P.L. 100-568 (1988).

157 Jamie Carlsteon et al., Copyright Renewal of U.S. Books Published in 1932: Re-analyzing Ringer's Study to Determine a More Accurate Renewal Rate for Books, 79 College \& Research Libraries 697 (2018), https://doi.org/10.5860/crl.79.5.697 (studying books published in 1932 and concluded that renewal rates were likely between 26 and 33 percent).

15817 U.S.C. § 108(h) (2018); Elizabeth Townsend Gard, Creating a Last Twenty (L20) Collection: Implementing Section 108(h) in Libraries, Archives and Museums (October 2, 2017),

http://dx.doi.org/10.2139/ssrn.3049158. 
Selecting books based on date of publication does not guarantee the that work is in the public domain, but it is an efficient way to use readily available bibliographic data to increase the chances, which in combination with CDL as an access strategy could lower overall risk of making those books digitally available.

\section{Out of Print and Off the Market}

The phrase "out of print" does not mean "out of copyright." In fact, many out of print works may still be under copyright. However, the out of print status of a book is meaningful for the fair use analysis. A key, though not necessarily determinative factor in fair use is whether or not the work is available to the potential user. If the work is out of print and unavailable for purchase through normal channels, the user may have more justification for reproducing it."159 A library might lower risk by selecting works for CDL implementation that are clearly not available in the marketplace, either "in print" from the publisher or electronically as a licensed e-book. Selecting these works has the practical risk mitigation strategy of also reducing the risk that anyone will bring suit in the first place - if the work is not currently exploited by its owner, chances stand to be higher that whoever that owner is isn't particularly concerned with use of it by libraries.

How to actually determine which books are not currently commercially exploited requires some investment of time and resources. Databases such as Bowker's Books in Print, and online searches through Amazon or Addall.com may be sufficient to give an indication that titles are no longer exploited through normal commercial channels. For older books, especially those without ISBNs, searches are more challenging. ${ }^{160}$

A second and far more severe category of "off the market" books are orphan works, which are works protected by copyright but which a user cannot, after a diligent search, identify the copyright holder. ${ }^{161}$ Although there have been

159 S.Rep. No. 94-473 (1975); Maxtone-Graham v. Burtchaell, 803 F.2d 1253, 1264 n. 8 (2d Cir. 1986) (out-of-print status of copyrighted book supports fair use determination); see also Part III(D)(2) (market failure for $20^{\text {th }}$ century books should favor fair use determination).

160 Low risk works published in the 1920s through the 1960s, if they have not been reissued after 1970, would not have an ISBN number, and so there is likely no present commercial exploitation. See Elizabeth Townsend Gard, "Creating a Last Twenty (L20) Collection: Implementing Section 108(h) in Libraries, Archives and Museums" (October 2, 2017). Available at SSRN: $\underline{\text { https:// ssrn.com/abstract=3049158 or http://dx.doi.org/10.2139/ssrn.3049158 }}$

161 See Library of Cong., Copyright Office, Notice of Inquiry: Orphan Works \& Mass Digitization, 77 Fed. Reg. 64555 (Oct. 22, 2012), https://perma.cc/6MHS-FZAH . (defining an orphan work as "an original work of authorship for which a good faith, prospective user cannot readily identify and/or locate the copyright owner(s) in a situation where permission from the copyright owner(s) is necessary as a matter of law."). See also HANSEN, supra note 15. 
several legislative proposals in the U.S. to facilitate use of orphan works, none have passed and orphan works do not have special legislative status under U.S. law. Orphan works, as described by the Supreme Court, are "older and more obscure works with minimal commercial value."162 But with copyright owners that are difficult or impossible to track down, Justices Breyer and Alito lament the "[u]nusually high administrative costs" that "threaten to severely limit distribution and use of those works...which, despite their characteristic lack of economic value, can prove culturally invaluable."163

Determining which works may be orphaned is potentially hard. However, it is clear that librarians, information professionals who are experts at searching for materials and determining provenance, are among the best suited to conduct such searches. ${ }^{164}$ With the research tools available, such as the online versions of the CCE and the Stanford Renewal Database, searching for the rightsholder for a potential orphan has been aided by the digital availability of these works. And, most recently, the U.S. Copyright Office released its registration card catalog online, which could make discovery of a registered work and its potential rightsholder even more effective. ${ }^{165}$

\section{Non-fiction and Factual Works}

Finally, a third collection characteristic that may reduce risk and enhance the fair use position is for libraries to focus their CDL efforts on works that are nonfiction or primarily factual. As a way to enhance the fair use position, the "nature of the work" factor tends to weigh more in favor of uses of works that are further from the core of what copyright was designed to protect. While courts have not placed significant weight on this factor, it still stands as a potential area for collection selection to enhance the fair use argument and lower risk.

Libraries have many choices. They may choose heavily factual or scientific books, or merely books that are categorized as non-fiction. They might also choose to apply CDL to books that incorporate significant amounts of non-

162 Golan v. Holder, 565 U.S. 302, 355 (2012) (Breyer, with whom Alito joined, dissenting).

$163 \mathrm{Id}$.

164 We do not believe libraries should adhere to rigid search standards that have been implemented in other jurisdictions, though they may provide useful guidance. Experience so far in those jurisdictions has shown that those search standards, rather than reliance on the reasoned expertise of information search professionals in line with general best practices, is not efficient or effective. See U.K. Intellectual Property Office, Orphan Works Dilligent Search Guidance for Applicants, (March 2018), https://www.gov.uk/government/publications/orphan-worksdiligent-search-guidance-for-applicants. See also Aura Bertoni, Flavia Guerrieri \& Maria Lillà Montagnanim, Requirements for Diligent Search in 20 European Countries ( ENDOW REPORT 2, JUNE 2017), http:// diligentsearch.eu/wp-content/uploads/EnDOW\%20Report\%202.pdf.

165 U.S. Copyright Office, Virtual Card Catalog (n.d.) https://vcc.copyright.gov/ 
protectable materials. Genealogical works, for example, or un-illustrated cookbooks may tend to include many materials unprotected by copyright. Similarly, works that incorporate significant quantities of U.S. government authored works (which are unprotectable in the United States) ${ }^{166}$ may also be targeted under the same rationale.

\section{CONCLUSION}

Controlled digital lending offers an incredible opportunity for opening up access to library collections. The Statement illustrates a growing list of libraries and librarians who support CDL as a concept. We acknowledge that law is not entirely settled. There are no cases directly on point, and some contrary authority in the context of commercial activities. Yet, there are strong arguments supported by caselaw for why CDL, appropriately tailored to reflect physical market conditions, should be permissible under existing law under the doctrine of fair use. We conclude that a library is acting within fair use if it digitizes and lends to users the full text of a copyrighted book, provided it does so within carefully implemented limits and safeguards (i.e. all the controls identified in the Statement), and provided that the library's primary purpose for making and using the digitized book is limited to uses that are within the distribution and related rights that all libraries have under the first sale doctrine, as applicable to the original book in the collection.

16617 U.S.C. $§ 105$ (2018). 